\title{
Hydrogeochemical Characterization of Rural Drinking Water in the Gauley River Basin, Monongahela National Forest
}

Arati A. Umarvadia

Follow this and additional works at: https://researchrepository.wvu.edu/etd

\section{Recommended Citation}

Umarvadia, Arati A., "Hydrogeochemical Characterization of Rural Drinking Water in the Gauley River Basin, Monongahela National Forest" (2016). Graduate Theses, Dissertations, and Problem Reports. 6847. https://researchrepository.wvu.edu/etd/6847

This Thesis is protected by copyright and/or related rights. It has been brought to you by the The Research Repository @ WVU with permission from the rights-holder(s). You are free to use this Thesis in any way that is permitted by the copyright and related rights legislation that applies to your use. For other uses you must obtain permission from the rights-holder(s) directly, unless additional rights are indicated by a Creative Commons license in the record and/ or on the work itself. This Thesis has been accepted for inclusion in WVU Graduate Theses, Dissertations, and Problem Reports collection by an authorized administrator of The Research Repository @ WVU. For more information, please contact researchrepository@mail.wvu.edu. 


\title{
Hydrogeochemical Characterization of Rural Drinking Water in the Gauley River Basin, Monongahela National Forest
}

\author{
Arati A. Umarvadia \\ Thesis submitted to the \\ Davis College of Agriculture, Natural Resources and Design \\ at West Virginia University
}

in partial fulfillment of the requirements for the degree of

Master of Science

in

Forestry

Nicolas Zegre, Ph.D., Chair

Joe Donovan, Ph.D.

Michael Strager, Ph.D.

Pamela Edwards, Ph.D.

Division of Forestry and Natural Resources

Morgantown, West Virginia
2016

Keywords: Groundwater; Geochemistry; West Virginia; Appalachian Plateau;

Monongahela National Forest

Copyright 2016 Arati A. Umarvadia 


\section{ABSTRACT \\ Hydrogeochemical Characterization of Rural Drinking Water in the Gauley River Basin, Monongahela National Forest}

\section{Arati A. Umarvadia}

In the Appalachian Plateau region, the heterogeneous coal geology and fractured bedrock aquifers has led to complexity in understanding groundwater resources in West Virginia. Groundwater is a major resource in the Monongahela National Forest where private residences, public works, and national forest operations all rely heavily on this resource. In recent years, Marcellus shale gas has been explored in a small region of the Gauley River Basin, within the boundaries of the Monongahela National Forest. Hydrogeochemical evaluation of groundwater was carried out in this region with the objective of establishing a baseline of groundwater chemistry prior to potential Marcellus development. Groundwater was analyzed from 48 wells over the 400-square kilometer study area and analyzed for 23 parameters including major and trace constituents, and stable isotopes. The multivariate methods of principal components analysis (PCA) and hierarchical cluster analysis (HCA) were combined with graphical methods (Piper, Stiff, Gibbs) to identify trends in water geochemistry. Samples were classified into three clusters: cluster 3 as deep groundwater, corresponding with high mineralization, valley settings, and silicate weathering processes; cluster 2 as shallower groundwater, corresponding with low mineralization, hilltop and hillside settings, and carbonate weathering processes; and cluster 1 as pristine groundwater, corresponding with little to no mineralization, predominantly occurring at hilltop settings and in groundwater springs. Overall, samples showed relatively low TDS that are indicative of fairly pure groundwaters. The increased mineralization from cluster 1 to cluster 3 is indicative of the evolution of groundwater along the flow path. This study establishes a baseline of groundwater chemistry and identifies that the chemical composition of groundwater in undeveloped regions of the Appalachian Plateau are relatively pure. Furthermore, groundwater chemistry is topographically distinct, with water-rock interactions along the groundwater flow path controlling the hydrogeochemistry in the region. 


\section{Acknowledgments}

A sincere thank you to my thesis committee, Dr. Nicolas Zegre, Dr. Joe Donovan, Dr. Pamela Edwards, and Dr. Mike Strager, whose insight and expertise greatly assisted this research. Funding was provided by the United States Forest Service Northern Research Station, Grant \# 11-JV-11242301-064. 


\section{Contents}

$\begin{array}{ll}\text { Abstract } & \text { ii }\end{array}$

Acknowledgments

Table of Contents $\quad$ iv

List of Tables $\quad$ v

List of Figures $\quad$ v

1 Introduction $\quad 1$

1.1 Review . . . . . . . . . . . . . . . . . . . . . . . . 1

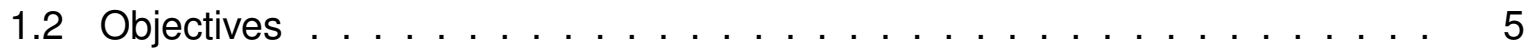

1.3 Study area description . . . . . . . . . . . . . . . . 7

2 Methodology 9

2.1 Site selection . . . . . . . . . . . . . . . . . . . . . 9

2.2 Sampling procedures . . . . . . . . . . . . . . . . . . . . . . . . . . . . . . . . . .

2.3 Water chemical analysis . . . . . . . . . . . . . . . . . . . 11

2.4 Graphical and statistical analysis . . . . . . . . . . . . . . . . . . . . 13

3 Results $\quad 16$

3.1 Hydrochemical characteristics . . . . . . . . . . . . . . . . . . . . . 16

3.2 Geochemical relationships between samples . . . . . . . . . . . . . . . . . 17

3.3 Topographic distribution of samples . . . . . . . . . . . . . . . . . . . . . . . . . . . . . . . . . . . . . .

3.4 Controls on groundwater chemistry . . . . . . . . . . . . . . . . . . . . 20

3.5 Isotopic Analysis . . . . . . . . . . . . . . . . . . . . . . . . . . . . . . . 21

4 Discussion $\quad 22$

4.1 Relationship between clusters and topographic setting . . . . . . . . . . . . 23

4.2 Types of weathering processes . . . . . . . . . . . . . . . . . . 24

4.2.1 Silicate weathering at deep settings . . . . . . . . . . . . . . 25

4.2 .2 Solution weathering at shallow settings . . . . . . . . . . . . . 27

4.2.3 Other trends throughout the region . . . . . . . . . . . . . . . 28

4.3 Hydrogeochemical evolution . . . . . . . . . . . . . . . . . . . . . 29

4.4 Pristine groundwater . . . . . . . . . . . . . . . . . . . . . . . . . . . . . . . . . . . . . . . . . . . . . . . . . . .

4.5 Isotopic analysis . . . . . . . . . . . . . . . . . . . . . . . . . 31

5 Implications and Conclusion 31 


\section{List of Tables}

1 Chemical parameters for private water wells in the Marcellus region . . . . 33

2 Hydrogeochemical dataset . . . . . . . . . . . . . . . . . 34

3 Descriptive statistics of dataset . . . . . . . . . . . . . . . . . 35

4 Geochemistry of topographic settings . . . . . . . . . . . . . . . 36

$5 \quad$ PCA loadings and proportion of variance $\ldots \ldots \ldots \ldots$

6 Geochemistry of HCA clusters . . . . . . . . . . . . . . . . . 38

7 Isotopic analysis of methane . . . . . . . . . . . . . . . . . . 39

\section{List of Figures}

1 Marcellus development in West Virginia . . . . . . . . . . . . . . 40

2 Historic Gauley River Subbasin . . . . . . . . . . . . . . . . . . . . . . . . . 41

3 Location of sample sites . . . . . . . . . . . . . . . . . . . . . 42

4 Probability of Marcellus development in West Virginia . . . . . . . . . . . 43

5 Location of natural gas pipelines . . . . . . . . . . . . . . . . . . 44

6 Histogram of Total Dissolved Solids . . . . . . . . . . . . . . . . . . . . 45

7 Piper diagram of sampling sites $\ldots \ldots \ldots \ldots$

8 HCA dendrogram . . . . . . . . . . . . . . . . . 47

9 Score plot of PC1 and PC2 . . . . . . . . . . . . . . . . . 48

10 Piper diagram of sampling sites, grouped by HCA cluster . . . . . . . . . . . 49

11 Stiff diagram of sampling sites, grouped by HCA cluster . . . . . . . . . 50

12 Piper diagram of sampling sites in the Gauley River Basin, Monongahela National Forest of West Virginia, grouped by topographic setting . . . . . . 51

13 Stiff diagram of sampling sites, grouped by topographic setting . . . . . . . 52

14 Gibbs diagram, grouped by HCA cluster . . . . . . . . . . . . . . . . 53

15 Gibbs diagram, grouped by topographic setting . . . . . . . . . . . . 54

16 Plot of ${ }^{13} \mathrm{C}-\mathrm{CH}_{4}$ vs. ${ }^{2} \mathrm{H}-\mathrm{CH}_{4}$ for methane origin determination $\ldots \ldots .55$

17 Relation between $\mathrm{Na}$ and $\mathrm{Cl} \ldots \ldots \ldots \ldots$

18 Stability field diagram of the $\mathrm{K}_{2} \mathrm{O}-\mathrm{Al}_{2} \mathrm{O}_{3}-\mathrm{SiO}_{2}-\mathrm{H}_{2} \mathrm{O}$ system $\ldots \ldots \ldots . \quad \ldots 5$

19 Relation between $\mathrm{Na}-\mathrm{Cl}$ and $\mathrm{Ca}+\mathrm{Mg}-\mathrm{SO}_{4}-\mathrm{HCO}_{3}{ }^{-} \ldots \ldots \ldots \ldots . \ldots . . \ldots 58$

20 Relation between $\mathrm{Ca}+\mathrm{Mg}$ and $\mathrm{HCO}_{3}{ }^{-}+\mathrm{SO}_{4} \ldots \ldots \ldots \ldots$ 


\section{Introduction}

\subsection{Review}

In the United States, metered and monitored public water supply sources serve the majority of the population. However, nearly $14 \%$ of the population use water from private domestic groundwater resources (US EPA, 2015). Groundwater resources in the United States are highly variable locally and regionally, driven by differences in geology, hydrology and land use. These varying characteristics alter groundwater flow and influence water chemistry. For private landowners, groundwater is often not monitored for water chemistry parameters or for adherence to the recommended drinking water primary and secondary maximum contaminant levels set forth by the Environmental Protection Agency (EPA). Without performing these analyses, landowners may experience adverse changes to their water quality that go entirely undetected, impacting their health or aesthetics of groundwater. Water quality monitoring may be especially important in areas that undergo land use change (altering the landscape or subsurface from its original state). Examples of land use change include mining, logging, animal feedlots, agriculture, industrial plants and oil/gas development. Rural areas are most susceptible to the impacts of land use change due to (1) the frequency of land use operations in rural areas and (2) the disproportionate number of residents who rely on groundwater for domestic supply.

In West Virginia, $42 \%$ of the population rely on groundwater, with $90 \%$ residing in rural areas using domestic groundwater resources (Chambers et al., 2012; Kozar and Mathes, 2001). Rural areas of West Virginia have seen significant land use change that has impacted water resources since the early 1900s, including impacts from logging, surface and underground coal mining, salt mining and conventional oil/gas development (Messinger and Hughes, 2000). However, coal lithology, commonly referred to as cyclothems, is one of the largest influences on water chemistry in the region. Cyclothems are sequences of 
sedimentary rock that alternate between marine and non-marine layers as the result of transgressive/regressive depositional environments (Abate, 1993; Harrison, 1983). Lithologic sequences of varying thickness typically include sandstone, shale, coal, underclay and limestone. In areas that have not experienced coal mining, groundwater flow is in a stairstep pattern (Sheets and Kozar, 2000). The primary matrix in these systems is limited to sandstone units with extremely low yield and little practical use, while secondary (fracture) permeability, such as bedding partings and stress-relief fractures, are the main conduit for groundwater flow (Wyrick and Borchers, 1981; Puente, 1984). Due to such heterogeneity in groundwater flow, temporal water quality monitoring to asses land use impacts over time are only effective when measurements are taken from the same location. If measurements are not spatially consistent through time, variability in water chemistry cannot be identified because chemical values may represent either interception of multiple strata by water-bearing fractures zones, different land use impacts or both. However, regional evaluations of water chemistry can be made and are useful to characterize regional drinking water quality as a baseline prior to new land use change.

West Virginia is experiencing a boom in land cover changes due to natural gas development. The main target formations in West Virginia are the Marcellus and Utica Shale, with Marcellus development, being the most wide-spread (Figure 1) (Repetski et al., 2005). The rapid expansion of unconventional gas development, that which uses hydraulic fracturing and horizontal drilling to release gas reserves from shale source rocks, has led to rising public concern over the effects of industry practices on water resources, specifically from contamination (US EPA, 2012; Rozell and Reaven, 2012; Adams, 2011; Gross et al., 2013; Soeder and Kappel, 2009; Soeder, 2011; Molofsky et al., 2013; Osborn et al., 2011). The EPA has reported the potential risks to drinking water resources from hydraulic fracturing (US EPA, 2012). These include the release risk of chemicals stored on-site prior to gas production via spills or leaks, the release of produced or flow back water during well development, and/or contaminated discharges from improper wastewater treatment (US EPA, 
2012). Concerns have also been raised of the potential for fresh-water aquifer contamination through vertical migration of subsurface brine and stray gas (Harrison, 1983; Myers, 2012; US EPA, 2012). Contamination of drinking water resources has potential to occur before, during and after phases of the gas development process (US EPA, 2012; Rozell and Reaven, 2012)

The two primary water quality concerns are changes in groundwater hydrogeochemistry and natural gas migration (Warner et al., 2012; Vengosh et al., 2014; Soeder and Kappel, 2009; Mathes et al., 2006; DiGiulio et al., 2011; Brantley et al., 2014). Water quality concerns from changes in hydrogeochemistry have been linked to gas development from surface and subsurface sources. Chloride and bromide have been found in high concentrations near shale gas sites, but high levels in some areas have been linked to upward migration of naturally occurring brines (Brantley et al., 2014). Surface sources of contamination may occur from transport of chemicals to and from the well site in the form of traffic accidents or improper handling (Rozell and Reaven, 2012). Spills can also occur through the mixing of chemicals on site or active well drilling (Rozell and Reaven, 2012; Gross et al., 2013), but the majority of surface spills or leaks are attributable to storage facilities such as tanks, impoundments or sludge pits, where equipment failure can lead to accidental releases (Gross et al., 2013; Lutz et al., 2013; Rahm et al., 2013). Furthermore, generated waste products from well stimulation, such as flowback or produced water, require proper disposal since storage is not a permanent solution. Common practices of wastewater disposal include underground injection, wastewater treatment or recycling (Brantley et al., 2014; Lutz et al., 2013). Underground injection has been used for both conventional and unconventional operations, however, in the Pennsylvania and New York regions of the Marcellus, geologic constraints do not allow for this type of disposal (Brantley et al., 2014; Lutz et al., 2013). Currently, recycling is becoming routine practice over treatment at industrial wastewater facilities, which typically leaves high chloride levels in the effluents (Brantley et al., 2014; Ingraffea et al., 2014). Drill cutting waste is treated as solid hazardous waste to be either 
buried on-site, or disposed of at industrial landfills (Brantley et al., 2014; Rahm and Riha, 2014). The potential for leaching from these disposal sites to contaminate shallow groundwater has been studied, although further research is necessary (Vengosh et al., 2014). Although surface spills or leaks on the land surface are known to occur, little research has been completed on the actual hydrogeochemical impacts to shallow groundwater resources.

Sources of stray gas include abandoned coal mines, landfills, legacy wells, natural migration from the subsurface through faults and fractures, or poor well construction resulting in well casing leaks that allow gas to seep into freshwater aquifers (Jackson et al., 2013b; Vengosh et al., 2014; Kappel et al., 2013; Vidic et al., 2013). Two studies have found increasing methane concentration in wells within $1 \mathrm{~km}$ of active gas wells (Jackson et al., 2013a; Osborn et al., 2011). Using isotope analysis, gas from these wells was found to have isotopic signatures indicative of deep or thermogenic origin, while methane traces found near inactive sites had signatures attributable to shallow or biogenic origin (Jackson et al., 2013a; Osborn et al., 2011). However, pinpointing the source of contamination is difficult without pre-drilling data, because methane gas has also been known to occur naturally in freshwater aquifers and coal beds overlying areas of the Upper Devonian Marcellus formation in West Virginia and New York (Molofsky et al., 2013; Sharma et al., 2014; NYS DEC, 2011).

Specific water quality parameters have been identified as signatures of gas development impacts (Table 1). Tiers rank the parameters that are most likely to be impacted from Marcellus shale activities (NYS WRI, 2011; PA DEP, 2010; OH EPA, 2014). The tiered parameters are those most likely to change in the event of gas development related contamination and therefore are important measurements when establishing baseline conditions. Due to uncertainties in natural background water quality, baseline water chemistry characterization prior to shale gas development is recommended to quantify any environmental changes, specifically in methane gas and hydrogeochemical concentrations. Concerns 
from stray gas include explosion hazards, changes to water chemistry including bacterial sulfate reduction, formation of toxic trihalomethanes (THMs) and water salinization (White and Mathes, 2006; States et al., 2013). Methane gas currently is not recognized by the EPA to have direct health hazards from ingestion, however, authorities recommend proper ventilation of well bores to prevent explosion hazards (Harrison, 1983). Guidelines for specific action levels have been proposed for areas where methane contamination is present including immediate action for concentratations $>28 \mathrm{mg} / \mathrm{L}$ and investigative measures for concentrations $10-28 \mathrm{mg} / \mathrm{L}$, no action is required for concentrations $<10 \mathrm{mg} / \mathrm{L}$ (Osborn et al., 2011; Eltschlager et al., 2001).

\subsection{Objectives}

The principal objective of this study is to characterize baseline geochemistry of mountain watersheds in a region of potential natural gas development. This region is the Gauley River Basin where recent gas and pipeline development has begun. Between 1980 and 1984, the groundwater hydrology of the Gauley River Basin was summarized for quality, geology and water chemistry as part of an investigation to map potable groundwater resources within the state of West Virginia (Figure 2) (McAuley, 1985). Previous research has been unable to identify specific shale gas impacts to the failure to establish baseline conditions prior to shale gas operations, or attribution of impacts to any number of other land uses, such as abandoned coal mines and nearby conventional wells (Jackson et al., 2013a; Myers, 2012). Therefore, this research will focus on an area of the Gauley River Basin with little historical land use change to determine a baseline geochemistry dataset prior to unconventional gas development. The study region lies within the Monongahela National Forest in Webster, Nicholas and Greenbrier county.

Many areas within the study region rely on groundwater for domestic use. Domestic 
wells are not subject to water quality testing by law and chemistry analysis is at the landowners expense. Often, rural domestic wells go untested for several years with landowners assessing their water quality from aesthetics alone. Without proper baseline testing for these valuable water resources, any regional or local change in groundwater chemistry due to natural processes or resource development are likely to go undetected and/or be misunderstood. Similar to private dependence on groundwater, the public campgrounds and recreation areas within the USFS Monongahela National Forest depend heavily on groundwater to provide potable water to the thousands of people visiting each year. Considering the large public and private dependence on this resource, it is crucial that the water be analyzed prior to drilling to ensure detection of any chemical changes that may occur.

Beginning in 2008, six shale gas well pads were constructed within the study area. Currently, only two well pads exist for designated future use (Figure 3) with no new drilling or steady production planned (WV GES, 2015). However, maps of future gas development probability indicate the current study region as having a medium chance of being developed in the future (Figure 4) (Johnson et al., 2010). Also, with the proposed construction of the Mountain Valley Pipeline in the northwestern section of the study region (EQT, 2015) (Figure 5), planned for completion in 2018, gas development and production may expand rapidly. This research will provide a baseline of the natural hydrogeochemistry of groundwater and regional hydrogeochemistry in an area with few land use types and prior to land use changes that have potential to contaminant shallow aquifers from surface spills, leaks and overall development. Furthermore, the research will aim to spatially characterize the shallow drinking water chemistry in the heavily visited portion of the Monongahela National Forest and to elucidate the hydrologic controls in the vicinity of expected unconventional gas development using baseline geochemistry.

The overall objective will be met by accomplishing the following specific objectives:

1. To assess changes in hydrochemistry between 1980 and the present; 
2. To determine the current hydrochemical characteristics of rural drinking water resources and the controls on groundwater composition;

3. To characterize the spatial and topographic distribution of water chemistry under current land use conditions

\subsection{Study area description}

The study area is located in the Monongahela National Forest within a subbasin of the Gauley River. The area includes Nicholas, Webster and Greenbrier counties. The selected study area encompasses 407 square kilometers within the Appalachian Plateau physiographic province (McAuley, 1985). The bedrock is composed of lower Pennsylvanian-aged sedimentary strata that are cyclical, nearly horizontal $\left(2^{\circ}-5^{\circ}\right.$ dip) and clastic in origin, con-

sisting of sandstone, shale, siltstone and coal sequences (Kozar and Mathes, 2001). Beds within the cyclothem vary in thickness from a few centimeters to several meters and commonly, discontinuities. Therefore, groundwater flow, controlled by the local topography, occurs in a stair-step pattern due to the effects of confining units (Kozar and Brown, 1995; Sheets and Kozar, 2000). In a stair-step flow pattern, water enters the system vertically at hilltops (recharge zone), percolates downward, until it intersects a more permeable fracture or bedding plane parting, the water will then move vertically or laterally until reaching the low point in they flow system (valleys)(Kozar and Brown, 1995; Sheets and Kozar, 2000). In this environment, mineralization of groundwater can occur as water percolates deeper into the subsurface, a product of rock weathering processes dependent on the lithology and solubility of the surrounding bedrock, as well as, residence time (Ghesquiere et al., 2015; Nahon, 1991). Typically, hilltops are unconfined and the principal area of groundwater recharge, 
usually leading to the freshest water (Kozar and Brown, 1995). As water moves along horizontal bedding plane separations and vertical stress-relief fractures, groundwater may intersect the surface and discharge as seeps, or flow into valleys that are partially or fully confined (Sheets and Kozar, 2000; Kozar and Mathes, 2001). The longer flow path increases water-rock interactions, leading to increased mineralization with depth (Ghesquiere et al., 2015; Nahon, 1991). Groundwater may discharge at hillsides as seeps where bedding planes intersect the surface (Kozar and Brown, 1995; Sheets and Kozar, 2000; Wyrick and Borchers, 1981). The majority of groundwater flow and storage occurs within 300 feet of the surface, where fractures from unloading are most pronounced (McAuley and Kozar, 2006). Most groundwater wells are completed within this shallow, fractured zone. The principal aquifers in the study are designated based on geologic age, and because the thickness of bedrock units often exceed average well depth, aquifers tend to mimic surface geology (WV GES, 2015; Kozar and Mathes, 2001) In the study region, the fractured bedrock aquifers are from the Pennsylvanian aged Pottsville group, subdivided into the Kanawha and New River formations, and the Bluestone and Princeton group. The fractures likely intersect at different lithological units; moreover, individual well water chemistry will be spatially variable due to interception of different rock mineralogy, dissolution rates, and variability in recharge source (McAuley, 1985; Sheets and Kozar, 2000). Comparative analysis among individual sites is difficult and dependent on water-rock interactions along fractures. Therefore, this study focuses on a regional characterization of the shallow drinking water, and determines spatial relationships at a larger scale. 


\section{Methodology}

\subsection{Site selection}

The target population includes private wells and public springs. The selected sampling sites (Figure 3) met the following attributes:

1. location within the study area and near/within the Monongahela National Forest proclamation boundary;

2. approximate known well depth;

3. accessible groundwater well, with operating in-line pump; or spring with known public use; and

4. raw water, no treatment or filtration.

The sampling sites were secured through field solicitation. All landowners were asked to sign informed consent forms to limit liability. Selected springs were those known to be used as public drinking water sources.

Additional sampling sites were secured from the online National Water Information System (NWIS) (U.S. Geological Survey, 2001). Historic sites were sampled between 1980-84. The selected historic sampling sites met the following attributes:

1. location within the study area and near/within the Monongahela National Forest proclamation boundary;

2. all major ion chemistry reported are from lab measurements;

3. parameters for $\mathrm{pH}$, conductivity and alkalinity are field measured; and

4. analysis is similar to present dataset (i.e. dissolved, filtered, total, etc.) 


\subsection{Sampling procedures}

Groundwater sampling procedures employed USGS field techniques for water chemistry monitoring (Wilde et al., 1998; Puls and Barcelona, 1989; Wilde, 1999). At each site, GPS coordinates were obtained. A 556 YSI handheld multi-parameter instrument was calibrated daily to manufacturer recommendations for field measurement of $\mathrm{pH}$, specific conductance, dissolved oxygen, and temperature. Three-point calibration was conducted with $\mathrm{pH}$ buffer solutions 4,7 , and 10 . One-point calibration of specific conductance was completed with $100 \mu \mathrm{S} / \mathrm{cm}$ solution of $0.01 \mathrm{M} \mathrm{KCl}$. One-point calibration of dissolved oxygen (DO) was completed to $100 \%$ saturation. Field alkalinity titration was conducted on $100 \mathrm{~mL}$ of filtered sample with $1.6 \mathrm{~N}$ or $0.16 \mathrm{~N}$ sulfuric acid in a $250 \mathrm{~mL}$ beaker using the Hach digital titrator to $\mathrm{pH}$ endpoint 3.9. Temperature $(\mathrm{T})$ and $\mathrm{pH}$ were monitored during titration using a $\mathrm{Hach} \mathrm{pH}$ probe calibrated daily to the provided manufacturer protocol at $\mathrm{pH}$ buffer solutions 4,7 , and 10.

Initial static water level was measured at select sites using the Soloist electric well tape. Raw water sample collection occurred most often from a spigot located outside the home or at the pressure tank. Wells were purged through a teflon line connected to the spigot and onto a manifold that split flow into a waste hose. Purging took place for 25-30 minutes until parameters ( $\mathrm{T}, \mathrm{pH}, \mathrm{DO}, \mathrm{SC})$ stabilized.

Post-purge, the manifold split flow into the sample line. Water was collected using lowflow techniques into a bucket (Wilde et al., 1998). Spring sampling was collected using dipsampling procedures (Wilde et al., 1998). At all sites, a $60 \mathrm{~mL}$ Luer-lock disposable syringe fitted with a $47 \mathrm{~mm} 0.45 \mu \mathrm{m}$ filter was used to fill plastic sample containers including one 250 $\mathrm{mL}$ bottle of filtered, unacidified sample collected for use in calculating field alkalinity; one $700 \mathrm{~mL}$ bottle grab sample, unfiltered, unacidified with no head space for anion analysis; two $200 \mathrm{~mL}$ bottles, one filtered and one unfiltered, preserved using nitric acid to $\mathrm{pH}<2$ for cation analysis (Wilde et al., 1998). 
Samples were stored on ice in the field and refrigerated until lab delivery was feasible. Lab analyses was conducted at the National Research Center for Coal and Energy Analytical (NRCCE) Laboratory in Morgantown, WV.

Four well sites were also analyzed for isotopes. At these sites, a 1 liter plastic collection bottle was submerged into a 19-liter bucket. The sample line inserted into the bottom of the bottle, rinsed for three sample volumes, then capped underwater with no headspace. A benzalkonium chloride capsule in the bottle cap was used to prevent microbial activity (Sharma et al., 2014). In addition, one $8 \mathrm{~mL}$ glass vial, unfiltered with no headspace was collected for hydrogen and oxygen analysis, and one $10 \mathrm{~mL}$ glass vial, filtered, preserved with three drops benzalkonium chloride, crimped with no headspace was collected for dissolved inorganic carbon (DIC) analysis. All bottles were wrapped in parafilm and refrigerated until analysis. Isotopic analysis was conducted at Isotech Laboratories (Champaign, IL).

\subsection{Water chemical analysis}

The water chemistry parameters were selected based on private water well quality testing protocols developed by the Water Research Institute (WRI), NY Department of Conservation (NY DEC), Pennsylvania Department of Environmental Protection (PA DEP), Pennsylvania State University (PSU), and the National Ground-Water Association (NGWA) in response to Marcellus development (PA DEP, 2010; OH EPA, 2014; NYS WRI, 2011) (Table 1). The parameters are tiered based on relative likelihood to undergo a change in response to Marcellus shale development processes and cost to landowners. All Tier 1 and most Tier 2 chemistry parameters were included in the analysis. Those not included were omitted due

to sampling costs and the assumption that parameters such as BTEX (benzene, toluene, ethylene, xylene), oil and grease, gross alpha and betas, surfactants, etc. do not occur in areas that have not undergone development, such as the study area. Parameters analyzed in this study include $\mathrm{pH}$, dissolved oxygen, specific conductance, temperature, alkalinity, $\mathrm{Cl}$, 
$\mathrm{F}, \mathrm{Br}, \mathrm{NO}_{3}, \mathrm{SO}_{4}, \mathrm{Fe}, \mathrm{Mn}, \mathrm{Ca}, \mathrm{Mg}, \mathrm{K}, \mathrm{Na}, \mathrm{SiO}_{2}, \mathrm{Se}, \mathrm{Cu}, \mathrm{Pb}, \mathrm{Al}, \mathrm{Ba}$, and As.

Twenty-four groundwater samples were collected in October and November 2015 and thirty-two historic groundwater samples were extracted from the National Water Information System (U.S. Geological Survey, 2001). Parameters with more than $20 \%$ samples below the minimum detection limit (MDL) were removed from further analysis in order to preserve analysis integrity (Farnham et al., 2002; Helsel, 1990). Several sampling sites had one or more chemical parameters below the MDL, including $\mathrm{NO}_{3}$, Fe, and $\mathrm{Mn}$. In order to include these samples in the analysis, it was chosen to substitute values with one-half the reporting limit (Helsel, 2006; Helsel and Hirsch, 1992; Helsel, 1990). The final parameters used in this study include the ions $\mathrm{Cl}, \mathrm{NO}_{3}, \mathrm{SO}_{4}, \mathrm{SiO}_{2}, \mathrm{Ca}, \mathrm{Mg}, \mathrm{K}, \mathrm{Na}, \mathrm{Fe}, \mathrm{Mn}$ and $\mathrm{HCO}_{3}{ }^{-}$from alkalinity titration. Alkalinity was calculated using the two-endpoint method for the present data:

Alkalinity (in CaCO3) $=\frac{(2 B-C)}{(800)} \cdot \frac{(N)(50,000)}{(V)}$

where $\mathrm{B}$ is the titrator digits to reach a $\mathrm{pH}$ of $4.2 ; \mathrm{C}$ is the titrator digits to reach a $\mathrm{pH}$ of 3.9; $\mathrm{N}$ is the normality of the acid; $\mathrm{V}$ is the volume of sample used in $\mathrm{mL} ; 800$ converts the titrator reading into $\mathrm{mL}$; and 50,000 is a conversion factor between equivalents of acid and $\mathrm{CaCO}_{3}$

Values were converted to $\mathrm{HCO}_{3}{ }^{-}$concentration in $\mathrm{mg} / \mathrm{L}$. Alkalinity was not measured in one sample with $\mathrm{pH}<4.5$ because alkalinity could not be measured with titration. The bicarbonate concentration in this sample was assumed to be $0 \mathrm{mg} / \mathrm{L}$. Historic sample values were reported in either $\mathrm{mg} / \mathrm{L}$ as $\mathrm{CaCO}_{3}$ or $\mathrm{HCO}_{3}^{-}$, all values were converted to $\mathrm{HCO}_{3}^{-}$ concentration in $\mathrm{mg} / \mathrm{L}$.

Prior to analysis, the dataset was separated into historic and present data to test for statistical similarity through time. Significance assessed at alpha $=0.05 . \mathrm{HCO}_{3}{ }^{-}$and $\mathrm{SO}_{4}$ reported p-values at 0.001 and 0.018 , respectively, indicating statistically significant differences in values. The differences in alkalinity concentrations are likely due to reporting 
errors in the historic dataset where a discrepancy were observed between $\mathrm{mg} / \mathrm{L} \mathrm{CaCO}$ and $\mathrm{mg} / \mathrm{L} \mathrm{HCO}_{3}{ }^{-}$measurements. For most samples, only one value was reported and potential error cannot be known. The differences in $\mathrm{SO}_{4}$ concentrations are likely due to natural spatial variation. All other parameter tests indicated no statistical differences between groups, justifying the combination of both datasets. Hence, historical and present survey datasets were combined for all further analysis $(n=56)$.

Each water sample was checked for accuracy by assessing the electro-neutrality of measured cations to measured anions. The error in this measurement is known as the charge balance error (CBE) (Freeze et al., 1979):

$\% C B E=\frac{\sum \text { cations }-\sum \text { anions }}{\sum \text { cations }+\sum \text { anions }} \cdot 100$

CBE was computed using Phreeqc (Parkhurst and Appelo, 1999) in order to account for ion speciation. Samples with CBE ranging from $0.03 \%$ to $10.84 \%$ met quality control requirements and were retained. Eight samples with $\mathrm{CBE}>10.84 \%$ were excluded from further statistical analysis. The final dataset consisted of 48 groundwater samples from wells and springs.

\subsection{Graphical and statistical analysis}

The hydrogeochemical data was analyzed using multivariate statistical approaches and graphical techniques in order to classify groundwater samples, group the dataset, and identify dominant hydrogeochemical processes. In this study, two multivariate methods were applied using $R$ ( $R$ Core Team, 2013): the principal components analysis (PCA) and the hierarchical cluster analysis (HCA); and three graphical techniques were used: Piper diagram, Stiff pattern diagrams, and Gibbs diagram.

Prior to analysis, chemical parameters were converted to meq/L and assessed for normal distribution using histograms. In multivariate analysis, normal and standardized datasets are required to ensure all parameters are weighted equally. The dataset showed a 
positive-skew and was therefore log-transformed to obtain an approximate normal distribution. Standardization was subsequently applied to the dataset to ensure that all parameters are weighted equally for the principal component analysis (Davis and Sampson, 1986a).

Principal component analysis, a non-parametric method for classification, was used to simplify the dataset and reduce the number of parameters to a few uncorrelated components. Each component is a linear combination of the original variables, which can be used to explain the variance in the dataset (Alberto et al., 2001). In this study, the principal components were interpreted to identify the dominant hydrogeochemical processes governing the natural variability of water chemistry in the region. PCA was performed using a singular value decomposition of the hydrogeochemical data matrix (R Core Team, 2013). The data can be reduced to the number of components explaining the maximum amount of variance. For this study, components with eigenvalues greater than 1 were retained (Davis and Sampson, 1986b; Cloutier et al., 2008). The PCA was applied to 10 parameters, including pH, $\mathrm{Ca}, \mathrm{Mg}, \mathrm{K}, \mathrm{Na}, \mathrm{HCO}^{-}, \mathrm{SO}_{4}, \mathrm{Fe}$, and $\mathrm{Mn}$. $\mathrm{NO}_{3}$ was excluded from the analysis because it had several sample values below the minimum detection limit. $\mathrm{SiO}_{2}$ was excluded from the analysis because it exhibited little variance in the region. An outlier was detected in data from sample 35 (Web-WV09) due to extreme $\mathrm{Cl}, \mathrm{Na}$, and $\mathrm{HCO}_{3}$ values and was therefore excluded from the PCA analysis.

Hierarchical cluster analysis (HCA) was subsequently performed in R (R Core Team, 2013) to interpret hydrogeochemical trends in the dataset. The HCA was used to identify similarities between samples (Meng and Maynard, 2001; Davis and Sampson, 1986a), i.e. a form of classification into groups. The HCA was applied to the factor scores from the PCA in order to reduce the number of variables used from the dataset (Ashley and Lloyd, 1978). Scores were used instead of the original variables in order to group samples in accordance with the components, and thereby dominant geochemical processes, identified from the PCA. The HCA was computed using Euclidean distance similarity coefficient (Meng and Maynard, 2001) and the Ward's criterion clustering method (Murtagh and Legendre, 2014). 
The resulting dendrogram classifies samples into clusters that can be further interpreted using additional techniques.

Graphical geochemical interpretation of each cluster was completed using Piper (Piper, 1944) and Stiff diagrams (Stiff, 1951) included in the Geochemist's Workbench software (Bethke, 2016). The Piper diagram is a common graphical approach used to classify groundwater by water type. The diagram consists of three plots: a ternary diagram of major cations $(\mathrm{Ca}, \mathrm{Mg}, \mathrm{Na}, \mathrm{K})$, a ternary diagram of major anions $\left(\mathrm{HCO}_{3}{ }^{-}, \mathrm{Cl}, \mathrm{SO}_{4}\right)$, and a diamond plot in the center, which is a matrix transformation of the cation and anion data (Piper, 1944). The Stiff diagram is a polygonal graphical approach used to visualize ionic differences between different waters. Diagrams are created using major ion concentrations in milliequivalents per liter (meq/L). Cations are plotted on the left axis $(\mathrm{Na}+\mathrm{K}, \mathrm{Ca}, \mathrm{Mg})$ and anions are plotted on the right axis $\left(\mathrm{Cl}, \mathrm{HCO}_{3}{ }^{-}+\mathrm{CO}_{3}{ }^{2-}, \mathrm{SO}_{4}\right)$ (Stiff, 1951). Patterns can be used to track flow path or find relationships between water groups (Ghesquiere et al., 2015).

Topographic setting of wells was extracted using ArcGIS 10.3 from the Ecological Land Units of West Virginia layer file (http://wvgis.wvu.edu/data/dataset.php?ID=452) available at the WV State GIS Data Clearinghouse. Landforms in the layer file were classified into 11 categories (cliff, steep slope, slope crest, upper slope, flat summit, side slope, cove, dry flat, moist flat, wet flat, slope bottom) based on a 9-meter Digital Elevation Model (DEM). These categories were reclassified into three topographic groups, hilltop (cliff, steep slope, slope crest, upperslope, flat summit), hillside (sideslope); and valley bottom (cove, dry flat, moist flat, wet flat, slope bottom), using the Spatial Analyst toolbox Reclassify tool. To determine the topographic setting of each sample, a 20-meter buffer zone was applied to ensure accurate determination of topographic setting, then a majority filter was applied to classify samples topographically. Each sample was assigned a topographic setting of hilltop, hillside, or valley. The reclassified topographic setting of samples were used to identify geochemical trends by topographic setting.

The Gibbs diagram (Gibbs, 1970) has been widely used in the literature (e.g., Kumar 
et al., 2014; Hounslow, 1995; Xing et al., 2013; Liu et al., 2015; Gupta et al., 2008) to characterize groundwater because it can infer broad-scale dominant controls on water chemistry, including precipitation, evaporation or rock-weathering and smaller signatures of mineralization, mixing, and freshening (Gibbs, 1970; Ghesquiere et al., 2015). The Gibbs diagram was used in this study to determine whether rock dissolution acts as a control on groundwater chemistry in the region. For the analysis, calculated values of TDS were plotted as a function of the ratio between major cations, $\mathrm{Na}+\mathrm{K}$ and $\mathrm{Na}+\mathrm{K}+\mathrm{Ca}$, or major anion, $\mathrm{Cl}$ and $\mathrm{Cl}+\mathrm{HCO}_{3}{ }^{-}$in milligrams/Liter.

\section{Results}

\subsection{Hydrochemical characteristics}

The Pennsylvanian fractured bedrock aquifer system has unique groundwater geochemistry due to the cyclothemic lithology in the Appalachian plateau. Groundwater wells typically intersect several water-bearing zones, and are exposed to several different layers of the bedrock sequence causing the chemical properties of groundwater to be highly variable (Sheets and Kozar, 2000). Groundwater chemistry in this region is predominantly controlled by the chemistry of recharge water, interactions with bedrock minerals as groundwater moves, and the residence time (Kozar and Brown, 1995). Due to this widespread heterogeneity, it is important to determine regional trends in groundwater chemistry as part of the baseline characterization for this study region.

The complete hydrogeochemical dataset of the 48 samples used in this study is presented in Table 2. The dataset includes field measurements, physical and geographic characteristics of sampling sites, and isotopic data for select sites. Table 3 presents descriptive statistics using data corrected to one-half the reporting limit for censored values (Helsel and Hirsch, 1992). Though several limitations exist for using one-half the reporting limit, 
this substitution method has been widely used in water resources (Helsel, 2006; Helsel, 1990).

The mean $\mathrm{pH}$ in the region is 6.60 with a 0.85 standard deviation, and is typical of natural groundwater (Hem, 1985). From the summary statistics it can also be inferred that bicarbonate and sodium were the most dominant anion and cation in the region, although highly variable with standard deviations of 48.37 and $26.51 \mathrm{mg} / \mathrm{L}$, respectively. The relative mean abundance of cations and anions in the groundwater is in the order of $\mathrm{Na}>\mathrm{Ca}>$ $\mathrm{Mg}>\mathrm{Fe}>\mathrm{K}>\mathrm{Mn}$ and $\mathrm{HCO}_{3}{ }^{-}>\mathrm{Cl}>\mathrm{SO}_{4}>\mathrm{NO}_{3}$. Total dissolved solids (TDS) were calculated by multiplying specific conductance by a conversion factor of 0.65 for natural waters (Rainwater and Thatcher, 1960). TDS is low for all samples, with a mean TDS of 97 $\mathrm{mg} / \mathrm{L}$. A histogram (Figure 6) shows the frequency distribution of TDS, most samples falling below $150 \mathrm{mg} / \mathrm{L}$. Geochemistry was further analyzed using a Piper diagram to plot the major cation and anion concentrations and examine the water types in the region (Figure 7). The Piper diagram illustrates that the chemical composition of groundwater in the study region is highly variable, consisting of seven different types. The most common water types in the region were $\mathrm{Ca}-\mathrm{HCO}_{3}(\mathrm{n}=13), \mathrm{Ca}-\mathrm{SO}_{4}(\mathrm{n}=13)$, and $\mathrm{Na}-\mathrm{HCO}_{3}(\mathrm{n}=9)$. Also occurring within the area are $\mathrm{Na}-\mathrm{Cl}, \mathrm{Mg}-\mathrm{Cl}, \mathrm{Mg}-\mathrm{SO}_{4}$, and $\mathrm{Ca}-\mathrm{Cl}$ water types. Due to the wide variability in groundwater type, principal components analysis (PCA) was used to reduce the number of variables and assist in identifying underlying hydrogeochemical processes that may be governing the natural variation of groundwater chemistry in the study region.

\subsection{Geochemical relationships between samples}

Principal components were extracted for 10 parameters $\left(\mathrm{pH}, \mathrm{Ca}, \mathrm{Mg}, \mathrm{K}, \mathrm{Na}, \mathrm{Cl}, \mathrm{HCO}_{3}^{-}\right.$, $\mathrm{SO}_{4}, \mathrm{Fe}, \mathrm{Mn}$ ). An outlier was detected in Sample 35 (Web-WV09) due to high values in $\mathrm{Cl}, \mathrm{Na}$, and $\mathrm{HCO}_{3}$ and was removed from the PCA analysis. It is unclear the cause of the extreme parameter values. A scatter-plot of component scores provides a graphical 
representation of each sample point and can be used to interpret chemical signatures of and major geochemical processes controlling groundwater chemistry in the region.

The principal component scores, derived from the PCA, describe the influence each component has on the individual groundwater samples. Much of the variance in the region is attributed to the first four principal components, retained due to eigenvalues greater than 1. The first four components account for $76.8 \%$ of the total variance in the dataset. Table 5 presents the principal component loadings for these four components. Component 1 explains the greatest amount of variance (34.09\%) and is characterized by $\mathrm{pH}, \mathrm{Ca}, \mathrm{HCO}_{3}$, and $\mathrm{Na}$ loadings. Component 2 describes $16.86 \%$ of the variance and is characterized by $\mathrm{K}, \mathrm{Mg}, \mathrm{SO}_{4}$, and $\mathrm{Fe}$. Component 3 describes $14.20 \%$ of the variance and is characterized by Fe and $\mathrm{Mn}$. Component 4 describes $11.63 \%$ of the variance and is characterized by $\mathrm{Cl}$. Using the scores from these four components to cluster samples will allow for an evaluation of the geochemical trends present in the dataset. However, it is important to recognize that computing cluster analysis on PC scores instead of the original variables introduces some error as this reduces the amount of information used to find associations (Ashley and Lloyd, 1978).

Hierarchical cluster analysis was conducted and a dendrogram of sample relationships was constructed. From visual analysis of the dendrogram (Figure 8), three principal clusters were identified. The dendrogram shows that cluster 2 and cluster 3 have a lower linkage distance between clusters, indicating that there is a greater geochemical relationship, with a likelihood of similar characteristics (Wu et al., 2014). Cluster 1, at the highest linkage distance, is mostly disconnected from the other clusters, indicating it will likely not share a close geochemical relationship with the other two sample clusters. Cluster 1, therefore, is likely the most unique of the dataset.

Additional evaluation of clusters using the PCA score plots (biplot) of PC1 vs. PC2, with HCA sample clusters identified, is presented in Figure 9. From visual observation, it can be noted that sample clusters are fairly distinct, with cluster 2 and cluster 3 sharing a large 
overlap, indicating a geochemical relationship (as expected from dendrogram observation). Cluster 1 is least influenced by the 10 parameters. Cluster 3 is characterized by influences from $\mathrm{Fe}, \mathrm{Mn}, \mathrm{Na}, \mathrm{pH}$, and $\mathrm{HCO}_{3}$. Cluster 2 is characterized by influences from $\mathrm{Ca}, \mathrm{Mg}, \mathrm{K}$, and $\mathrm{SO}_{4}$. This indicates that cluster 1 is largely unaffected by the processes represented in PC2, cluster 3 is identified by the processes represented in PC1, and cluster 2 has influences from both PC1 and PC2. Also, cluster 2 and 3 are highly mineralized with the major ions, while cluster 1 is not.

Table 6 describes the summary characteristics of each cluster, including the mean of 10 chemistry parameters, TDS (total dissolved solids), well depth, land elevation, and water type. Each sample cluster was plotted individually on a Piper diagram to visually asses water type (Figure 10). Stiff diagrams were developed using mean concentrations in meq $/ \mathrm{kg}$ of major-ion chemistry to visualize ionic differences between clusters (Figure 11).

Using Figure 11, clusters were characterized. Cluster 1 samples are $\mathrm{Na}-\mathrm{Ca}-\mathrm{HCO}_{3}$ type groundwater. Cluster 1 has the lowest concentrations of $\mathrm{Ca}, \mathrm{Mg}, \mathrm{K}, \mathrm{Na}, \mathrm{HCO}_{3}$, and $\mathrm{Mn}$, with the highest concentrations in $\mathrm{Cl}$. Measurements of conductivity, TDS, and $\mathrm{pH}$ are also lowest in this cluster. Cluster 2 is $\mathrm{Ca}-\mathrm{Mg}-\mathrm{HCO}_{3}$ and $\mathrm{Ca}-\mathrm{Mg}-\mathrm{SO}_{4}$ dominant groundwater. Cluster 2 has the highest concentrations in $\mathrm{SO}_{4}, \mathrm{Ca}$, and $\mathrm{Mg}, \mathrm{HCO}_{3}$, and $\mathrm{K}$. Cluster 3 , a $\mathrm{Na}-\mathrm{Ca}-\mathrm{HCO}_{3}$ and $\mathrm{Ca}-\mathrm{Mg}-\mathrm{SO}_{4}$ type groundwater, has the highest concentrations of $\mathrm{Na}, \mathrm{Fe}$, $\mathrm{Mn}$, conductivity, and TDS, and elevated concentrations in $\mathrm{Ca}$ and $\mathrm{HCO}_{3}$. All clusters are distinct, with samples in cluster 2 and cluster 3 sharing the most similarity as both have elevated concentrations of several parameters. As noted by the PCA, cluster 1 has the lowest concentrations of all parameters. A relationship also exists between land elevation and topographic setting for the three clusters. Land elevation decreases from cluster 1 to cluster 3. Cluster 1 and cluster 2 are more closely associated with hilltop and hillside topographic settings, and cluster three is largely associated with valley settings. 


\subsection{Topographic distribution of samples}

To assess the relationship between land elevation and topographic setting, the GIS-based topographic analysis grouped samples into hilltop $(n=20)$, hillside $(n=11)$, and valley $(n=17)$ settings. Table 4 presents the summary statistics in $\mathrm{mg} / \mathrm{L}$ by topographic position, including the mean of 10 chemistry parameters, TDS (total dissolved solids), well depth, land elevation, and water type. Hilltop settings have a 5.90 mean $\mathrm{pH}, 67 \mathrm{mg} / \mathrm{L}$ dissolved solids, high concentrations of $\mathrm{HCO}_{3}{ }^{-}$and $\mathrm{Ca}$, and the predominant water type is $\mathrm{Ca}-\mathrm{Mg}-\mathrm{SO}$. Hillside settings have a 6.34 mean $\mathrm{pH}, 107 \mathrm{mg} / \mathrm{L}$ dissolved solids, high concentrations of $\mathrm{HCO}_{3}{ }^{-}$, $\mathrm{Ca}, \mathrm{Cl}$, and $\mathrm{SO}_{4}$, with $\mathrm{Ca}-\mathrm{HCO} 3$ and $\mathrm{Na}-\mathrm{Ca}-\mathrm{Cl}$ water types. Valley settings have a 7.13 mean $\mathrm{pH}, 142 \mathrm{mg} / \mathrm{L}$ dissolved solids, high concentrations of $\mathrm{HCO}_{3}^{-}, \mathrm{Na}, \mathrm{Ca}$, and $\mathrm{Cl}$, with a dominant $\mathrm{Na}-\mathrm{Ca}-\mathrm{HCO} 3$ water type. As groundwater moves from hilltop to valley settings, TDS, $\mathrm{pH}, \mathrm{HCO}_{3}^{-}, \mathrm{Na}$, and $\mathrm{Cl}$ increase. Water type was determined by plotting groups on a Piper diagram (Figure 12). Stiff diagrams were also developed using mean concentrations in $\mathrm{meq} / \mathrm{kg}$ of major-ion chemistry to visualize ionic differences between topographic groups (Figure 13).

\subsection{Controls on groundwater chemistry}

Water samples plotted on the Gibbs diagram Gibbs (1970) are presented in Figure 14 and Figure 15. The majority of samples plot near the center of the diagram, identifying bedrock dissolution as the principle driver of water chemistry in the region. Water samples were plotted with clusters identified. Cluster 1 samples have low TDS and high anionic ratios, which is consistent with its dilute major-ion chemistry (Table 6). Cluster 1 plots predominantly in the freshening zone, far from the centroid of mineralization. Cluster 2 and 3 plot closest to the centroid suggesting they are highly mineralized, predominantly influenced by water-rock interactions (Ghesquiere et al., 2015). Cluster 2 have a wide anionic ratio range and plot across the rock dominant and early-mineralization zone. Cluster 3 samples are 
predominantly in the mineralized zone at the centroid. Samples move closer to the centroid (rock-dominance) as they become increasingly mineralized and distinguished by the bedrock geology, and is characteristic of deep or old groundwater (Ghesquiere et al., 2015). These observations are consistent with the previous analysis of cluster mean geochemistry where cluster 1 is fairly pristine water primarily hilltop and spring samples, and cluster 2 and cluster 3 are highly mineralized, occurring in valley settings and lower land elevations (Table 6).

\subsection{Isotopic Analysis}

Isotopic analysis was applied at four of the forty-eight sites for which methane, dissolved inorganic carbon, and oxygen isotopes were measured. Samples with detectable methane concentrations were evaluated graphically using ${ }^{13} \mathrm{C}-\mathrm{CH}_{4}$ and ${ }^{2} \mathrm{H}-\mathrm{CH}_{4}$ signatures to determine methane origin (Sharma et al., 2014). Where dissolved methane concentrations are $>0.1 \mathrm{mg} / \mathrm{L},{ }^{13} \mathrm{CCH}_{4}$ and ${ }^{2} \mathrm{HCH}_{4}$ signatures can be used to determine the biogenic or thermogenic origin of methane (Sharma et al., 2014). The values of ${ }^{13} \mathrm{CCH}_{4}$ and ${ }^{2} \mathrm{HCH}_{4}$ can be plotted graphically to determine whether samples are from thermogenic, $\mathrm{CO} 2$ reduction (microbial/biogenic) or of mix origin (Whiticar, 1999; Sharma et al., 2014) (Figure 16). Isotope results are presented in Table 7. Of the four samples that were analyzed for methane, only one site (Sample 41- Web-WV 15) had detectable levels of methane, at high enough concentrations to undergo isotope analysis. Methane concentrations are $-59.6{ }^{13} \mathrm{CCH}_{4}$, $200.9{ }^{2} \mathrm{H}-\mathrm{CH}_{4}$. The sample plots between microbial and thermogenic gas on Figure 16, therefore, methane origin cannot be determined. 


\section{Discussion}

The primary goal of this study was to characterize the baseline groundwater chemistry in the Gauley River basin. In the Appalachian Plateau region, flat-lying cyclothemic sequences of sedimentary bedrock create a highly variable groundwater environment. Groundwater interpretation through graphical methods used in this study can be crucial for evaluation of water type, identifying trends between samples, and identifying the dominant sources of ionic constituents within the region. However, caution must be taken as much of the interpretation is complicated by fractured geologic settings where chemistry can yield mixed signals because groundwater may be intercepting multiple lithologic zones (Sheets and Kozar, 2000; Kozar and Mathes, 2001). These techniques are conventional approaches to identify water samples with similar chemical composition and establish groups. The common assumption is that waters sharing chemical signatures can originate from similar recharge areas, flow paths, or geochemical processes. Also, waters that are in regions without disturbance, such as the study area, are likely to remain pristine. A majority of samples in our study area had TDS concentrations below $150 \mathrm{mg} / \mathrm{L}$, indicating a local rather than regional flow network, and fresh conditions (Hem, 1960). Further, in the current study region, little change between historical and present day datasets was detected, but local differences in groundwater chemistry do exist. We see definitive hydrogeochemical groups along the groundwater flow path, identifying increased mineralization as groundwater evolves from hilltop to valley settings. This relationship is expected considering the local flow system where groundwater moves in a stair-step pattern (Sheets and Kozar, 2000). Using our geochemical analysis, we are able to understand the mechanisms driving mineralization and how groundwater evolves from shallow to deeper subsurface environments. 


\subsection{Relationship between clusters and topographic setting}

From the Gibbs diagram (Figure 14 and 15) it was determined that bedrock dissolution and geology act as the broad-scale primary control on hydrochemistry. This observation is consistent with other Appalachian-region research (Kozar and Mathes, 2001; Sheets and Kozar, 2000; Messinger, 1997). Furthermore, when the Gibbs diagram is analyzed by cluster and topographic groups (Figures 14 and 15), it was observed that each group plots with similar distinction. Analysis of cluster groups indicates that land elevation decreases between cluster 1 and cluster 3. We can infer that visual similarities between Gibbs diagrams and the trend in land elevation predicts a relationship between cluster 1 and hilltop settings, cluster 3 and valley settings, and cluster 2 and hilltop/hillside settings. The relationship is indicative of the increased mineralization along the groundwater flow path that occurs with decreasing land elevation, observed between clusters 1 and 3 (Table 6). Furthermore, PCA biplot analysis confirms this observation of increased mineralization as cluster 1 samples are largely pristine, and act as outliers. Mineralization of groundwater is a product of rock weathering processes that are dependent on the type and solubility of the bedrock, as well as, residence time (Ghesquiere et al., 2015; Nahon, 1991). The relationship between clusters and topographic groups suggests that the hydrogeochemically distinct clusters are products of location along the groundwater flow path.

A closer look at the geochemical relationship between topographic setting and cluster groups was conducted using Piper and Stiff diagrams, both groups were graphically compared to determine if major-ion associations exist. The Piper diagram tested for correlations in water type. Figures 12 and 10 illustrate that cluster 1 and hilltop settings are predominantly Ca-Mg-SO4 water type, and cluster 2 and 3 , and hillside/hilltop settings are $\mathrm{Ca}-\mathrm{Mg}-\mathrm{SO} 4$ and $\mathrm{Na}-\mathrm{Ca}-\mathrm{HCO}$. Figures 13 and 11 further illustrate that a similar pattern of major-ions is observed between clusters and topographic groups. The cluster 1 and 
hilltop samples both show a pattern of low mineralization and little major-ion activity. Concentrations of $\mathrm{Ca}$ and $\mathrm{Cl}$ are slightly elevated. Similarities between cluster 2 and 3 and hillside/hilltop samples show a pattern indicative of high major-ion activity, with dominant $\mathrm{Na}+\mathrm{K}, \mathrm{Ca}$, and $\mathrm{HCO}_{3}$ ions. The similarity in ionic pattern observed between groups in the Piper and Stiff diagrams confirm that geochemical spatial variability in the study region is the result of topographic position, location along the groundwater flow path. The increase in size of the diagram from cluster 1 to cluster 3 illustrates the increasing mineralization originally noted from the Gibbs diagram as groundwater evolves (Figures 14 and 15).

Kozar and Brown (1995) confirms that in the sedimentary bedrock aquifers of the Appalachian plateau, chemical changes occur as water moves downward from hilltop to valley settings. The historical variation in chemical quality as water flows into valleys is reported as increased TDS and increased concentrations in $\mathrm{Ca}, \mathrm{Mg}, \mathrm{Fe}, \mathrm{Mn}$, and $\mathrm{Na}$ (Moody et al., 1988; Kozar and Brown, 1995). The measurements of clusters in the current study show similar variation. Loughnan (1969) noted that groundwater composition is predominantly controlled by the breakdown of the parent material from the infiltration of meteoric waters downward through bedrock. Typically, the resulting chemical signature can be used to identify the nature and extent of rock weathering processes occurring in the subsurface. Therefore, using the chemical composition for each cluster, the chemical weathering processes for the study region were identified.

\subsection{Types of weathering processes}

The majority of the rock in the crust is comprised of silicate minerals. In the Appalachian plateau, much of the inter-granular cementation of sediments is comprised of silicates, and to a lesser extent carbonates (Nahon, 1991; Sheets and Kozar, 2000; Wyrick and Borchers, 1981). Therefore, silicate and carbonate weathering are the most important processes driving groundwater chemistry in the region. Due to the region's sedimentary origin, many 
minerals are unstable and susceptible to chemical weathering by atmospheric or water interaction (Loughnan, 1969). Weathering processes influencing groundwater composition can include solution, hydrolysis, and/or oxidation-reduction (Carroll, 2012), often with more than one reaction occurring simultaneously (Ollier, 1984).

\subsubsection{Silicate weathering at deep settings}

An important mechanism by which silicate weathering occurs is hydrolysis. In this process, the parent minerals and surrounding water interact, replacing cations with hydrogen ions on the mineral surface, therefore resulting in decomposition of the bedrock (Ollier, 1984). In sedimentary rocks, quartz, feldspars and micas are the most common weathering parent minerals (Loughnan, 1969). These silicates (except quartz) are those likely to be chemically weathered by hydrolysis. The consumption of $\mathrm{H}^{+}$ions and release of cations from silicate weathering reactions increases the $\mathrm{pH}$ of groundwater, and can form a ion-rich solid residue to form new minerals (Loughnan, 1969). The type of resultant clay is dependent upon the composition of the ion-rich residue and the original silicate crystalline structure (Loughnan, 1969).

Because cations are released during silicate weathering, the dominant cation, sodium, was used to confirm the occurrence of silicate weathering processes in the study region. Several studies have used the $\mathrm{Na} / \mathrm{Cl}$ ratio as means for determining if silicate weathering, evaporation/evapotranspiration, or halite dissolution are driving the release of sodium ions (Kumar et al., 2006; Fisher and Mullican III, 1997; Cerling et al., 1989; Ghesquiere et al., 2015). If $\mathrm{Na} / \mathrm{Cl}$ concentrations are close to equal and plot on a 1:1 line, samples are likely influenced by halite dissolution (Kumar et al., 2006; Cerling et al., 1989). However, if concentrations remain unchanged, evaporation/evapotranspiration is the dominant process (Rajmohan and Elango, 2004). If $\mathrm{Na}$ exceeds $\mathrm{Cl}$ concentrations, samples are likely subject to silicate weathering processes (Kumar et al., 2006). In the current study, cluster 3 has 
a mean $\mathrm{Na} / \mathrm{Cl}$ ion ratio of 5.32 (Figure 17). The high ratio for cluster 3 samples indicates that deep groundwater, such as in valley settings, is predominantly controlled by silicate weathering processes.

Furthermore, as silicates dominate the study area (Sheets and Kozar, 2000), aluminosilicates, such as potassium feldspar, can weather to produce an ion-rich residue leading to the formation of secondary clay minerals, such as kaolinite. An example of such a reaction, known as incongruent dissolution (Carroll, 1959), is:

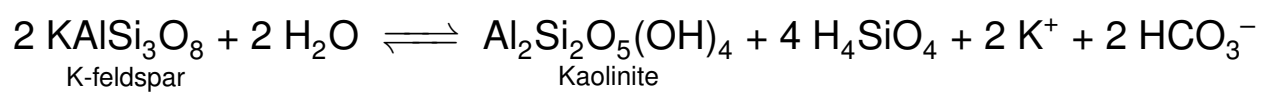

This process releases $\mathrm{HCO}_{3}^{-}$ions, silica, kaolinite, and $\mathrm{K}^{+}$ions. To determine which solid mineral phases were in equilibrium with the groundwater, the stability field relationships for the $\mathrm{K}_{2} \mathrm{O}-\mathrm{Al}_{2} \mathrm{O}_{3}-\mathrm{SiO}_{2}-\mathrm{H}_{2} \mathrm{O}$ system were identified (Loughnan, 1969). Samples with clusters identified were plotted using the effective concentrations (activity) of silicic acid $\left(\mathrm{H}_{4} \mathrm{SiO}_{4}\right)$ and ratio of $\mathrm{K}^{+}$to $\mathrm{H}^{+}$(Figure 18). Activity concentrations were derived using Phreeqc (Parkhurst and Appelo, 1999). All groundwater samples plot within the kaolinite stability field, indicating that clay mineral is considered the stable mineral phase formed during the hydrolysis of silicates in the study region (Powell and Larson, 1985).

Within the kaolinite stability field, clusters are fairly distinct. Greater activity concentrations are associate with longer residence times and therefore, the separation of clusters likely represents the evolution of groundwater in the system. Specifically as effective concentrations increase between cluster 1 and cluster 3 , samples evolve, becoming closer to equilibrium with muscovite or microcline. Overall, clay minerals are very persistent in sedimentary environments due to their occurrence as a weathering byproduct.

The presence of clay also brings the potential for cation-exchange reactions to occur. lon-exchange is the replacement of an ion negatively held by the mineral surface with an ion in the surrounding waters, further influencing the groundwater chemistry (Loughnan, 1969). 
For cluster 3, the elevated $\mathrm{Na}$ concentrations, combined with $\mathrm{HCO}_{3}{ }^{-}$as the dominant anion, and low $\mathrm{Ca}+\mathrm{Mg}$ concentrations have been suggested by many to indicate the presence of cation-exchange reactions (Cerling et al., 1989; Lakshmanan et al., 2003; Fisher and Mullican III, 1997). A -1 relationship between $\mathrm{Na}-\mathrm{Cl}$ and $\mathrm{Ca}+\mathrm{Mg}-\mathrm{SO}_{4}-\mathrm{HCO}_{3}{ }^{-}$can indicate more precisely whether cation-exchange is a dominant geochemical process contributing to the geochemistry of deep groundwater. Cluster 2 samples share a similar trend, however $\mathrm{Na}$ concentrations are lower than Cluster 3 . Cluster 3 samples fall close to a straight line (slope $=-0.80$ ), with some deviation ( $\mathrm{r} 2=0.92)$, confirming cation-exchange as an additional mechanism influencing groundwater composition in deep settings (Figure 19). Cation exchange reactions are commonly observed in regions with shale and clay lithology (Cerling et al., 1989). The prevalence of $\mathrm{Ca}-\mathrm{HCO}_{3}$ rich waters in upland areas and $\mathrm{Na}-\mathrm{HCO}_{3}$ rich waters in lowlands indicates that the cation exchange is occurring between sodium and calcium, leading to the more sodium-rich waters in deeper groundwater (Sheets and Kozar, 2000). Cation exchange likely increases with depth. The combination of hydrolysis and ionexchange are the drivers of water chemistry in deep settings. Overall, dominant ions of $\mathrm{Na}$ and $\mathrm{HCO}_{3}{ }^{-}$, with increased $\mathrm{pH}$ are signatures of silicate weathering processes (Loughnan, 1969).

\subsubsection{Solution weathering at shallow settings}

Shallow settings, such as hilltops, vary from deep settings, such as valleys, because there are more climatic influences. Solution occurs as atmospheric $\mathrm{CO}_{2}$ dissolves in recharge waters to form carbonic acid $\left(\mathrm{H}_{2} \mathrm{CO}_{3}\right)$ (Appelo and Postma, 2004). The carbonic acid dissolves parent mineral constituents, decreasing the stability of the original mineral structure (Appelo and Postma, 2004). An specific example of solution is carbonation by which carbonates dissolve, namely calcite $\left(\mathrm{CaCO}_{3}\right)$, dolomite $\left(\mathrm{CaMg}\left(\mathrm{CO}_{3}\right)_{2}\right)$, and gypsum $\left(\mathrm{CaSO}_{4} \cdot \mathrm{H}_{2} \mathrm{O}\right)$. A example of such a reaction is: 
$\underset{\text { Calcite }}{\mathrm{CaCO}_{3}}+\mathrm{CO}_{2}+\mathrm{H}_{2} \mathrm{O} \rightleftharpoons \mathrm{Ca}+2 \mathrm{HCO}_{3}$

Hilltop settings as the principal recharge areas are most influenced by rainfall and solution processes. Results of the $\mathrm{Na} / \mathrm{Cl}$ ratio analysis described previously indicate that cluster 1 has a $0.27 \mathrm{Na} / \mathrm{Cl}$ mean ratio (Figure 17). Chloride deposition was measured at input rates of $2.1 \mathrm{~kg} / \mathrm{ha}^{*}$ year in a forested area within the Monongahela National Forest, an area comparable to the study region (Svensson et al., 2012). Therefore, the higher $\mathrm{Cl}$ concentrations than $\mathrm{Na}^{+}$suggest that $\mathrm{Cl}$ inputs are likely from rainwater, soil organic matter or anthropogenic influences (i.e. road salts), because no halite or marine water occur in the study region (Fisher and Mullican III, 1997; Kozar and Brown, 1995; Svensson et al., 2012). Moreover, silicate weathering is not a dominant control in shallow settings. Using a plot of $\mathrm{Ca}+\mathrm{Mg}$ as a function of $\mathrm{HCO}_{3}{ }^{-}+\mathrm{SO}_{4}$, the prevalence of silicate weathering and carbonate weathering were determined (Figure 20). A 1:1 line differentiates the two processes. The plot of cluster 1 (Figure 20) samples illustrates that samples plot near and slightly above the $1: 1$ line. This indicates that carbonate solution, likely from carbonate cement (Sheets and Kozar, 2000) is the primary driver of groundwater composition at shallow settings. The prevalence of $\mathrm{Ca}-\mathrm{SO} 4$ and the graphical representation shallow samples portray on the Piper diagram could indicate gypsum dissolution within the region (Kozar and Brown, 1995; Hounslow, 1995). Alternatively, it is possible that partial oxidation of pyrite within shale units is facilitating the release of sulfate (Cerling et al., 1989). Another possible source is atmospheric deposition of sulfate (Hem, 1960). Overall, the lack of major-ions at cluster 1 , presence of chloride and sulfate, are indicative of shallow settings where relatively new, pristine water exists.

\subsubsection{Other trends throughout the region}

Iron and manganese was detected in samples collected throughout the region, a common occurrence in coal environments. The heterogeneity of cyclothemic bedrock and lack of 
oxidation-reduction potential (ORP, Eh) data, however, hinder our ability to pinpoint specific processes that are contributing to iron and manganese signatures found in the groundwater. Therefore, saturation indicies derived from Phreeqc (Parkhurst and Appelo, 1999) were used to infer probable mineral-water relationships and determine the mineral source of iron. Using the geochemical composition of the water, Phreeqc determines a saturation index (SI) of minerals that are likely to occur in the subsurface given the distribution of chemical constituents. A SI of less than zero indicates the water is undersaturated and the mineral is dissolving, while a SI of greater than zero indicates supersaturation and the mineral is precipitating (Powell and Larson, 1985). A SI of zero indicates equilibrium. Typically, Fe in anoxic groundwater can originate from the partial oxidation of pyrite $\left(\mathrm{FeS}_{2}\right)$, from the dissolution of iron-rich minerals, or reduction of iron-oxides (Appelo and Postma, 2004). Using the saturation indicies, it was determined that the partial oxidation of pyrite, and siderite $\left(\mathrm{FeCO}_{3}\right)$ dissolution, are the likely sources of iron in the region. Both minerals are common constituents in sedimentary rocks within coal environments (Appelo and Postma, 2004). The processes by which ferrous iron is released from each mineral are:

$$
\begin{aligned}
& \underset{\text { Pyrite }}{2 \mathrm{FeS}_{2}}+7 \mathrm{CO}_{2}+2 \mathrm{H}_{2} \mathrm{O} \rightleftharpoons 2 \mathrm{Fe}^{2+}+4 \mathrm{SO}_{4}{ }^{2-}+4 \mathrm{H}^{+} \\
& \underset{\text { Siderite }}{\mathrm{FeCO}_{3}}+\mathrm{H}_{2} \mathrm{CO}_{3} \rightleftharpoons \mathrm{Fe}^{2+}+2 \mathrm{HCO}_{3}^{-}
\end{aligned}
$$

\subsection{Hydrogeochemical evolution}

Groundwater evolves in the Appalachian plateau system by moving from preferential recharge zones at hilltops, down-gradient through the fractured bedrock within the ridge into hillslopes, discharging at hillsides seeps, or continuing to move through fractured strata into the valley. The chemical evolution of groundwater along the flow path has been determined to be topographically controlled (Kozar and Brown, 1995), as shown in this study. Water flows in a stair-step pattern from hilltops to valleys, with discharge along intersections of 
bedding planes at hillsides (Kozar and Brown, 1995; Sheets and Kozar, 2000). Cluster 3 is most characteristic of hilltop settings which are the principal recharge zones, as noted by the high chloride levels, indicative of rainfall. Carbonate weathering processes dominate in this region. Water in this zone has low TDS, indicative of new groundwater that has not been in contact with the bedrock for very time (Freeze et al., 1979). As water continues moving through the system into hillside settings, groundwater influences become a mix of carbonate and silicate weathering, represented by the ambiguity of cluster 2. Cluster 1 demonstrates the highly mineralized groundwater of water in the fractured valley settings. Groundwater composition is the result of longer residence times and silicate weathering processes such as, hydrolysis and cation exchange. Water in valley settings has increased $\mathrm{pH}$ and high $\mathrm{HCO}_{3}{ }^{-}$concentrations due to silicate processes. In addition, the occurrence of pyrite oxidation and siderite dissolution contribute to iron concentrations throughout the region. Though not a dominant hydrogeochemical signature on its own, the prevalence suggests that coal lithology influences groundwater chemistry. Overall, these processes are the primary controls contributing to the composition of water chemistry in the study region.

\subsection{Pristine groundwater}

The analysis indicates that groundwater samples in this undisturbed, forested region are controlled largely by mineralization along the groundwater flow path. Though mineralization exists, groundwater samples exhibit a low mean TDS of $97 \mathrm{mg} / \mathrm{L}$ (Figure 6), which is largely indicative of fresh, pristine water Hem (1960). For cluster 1, a mixture of springs and hilltop wells, has a mean TDS of $42 \mathrm{mg} / \mathrm{L}$, a value close to reported values of rain Hem (1960). The low values of TDS signify that undisturbed landscapes in West Virginia, where little to no mineral extraction has occurred, waters remain pure and natural. 


\subsection{Isotopic analysis}

Isotopes were used to determine the presence of methane and source. Methane concentrations were detected at one location with detectable traces at $>0.1 \mathrm{mg}$. The ${ }^{13} \mathrm{CCH}_{4}$ and ${ }^{2} \mathrm{HCH}_{4}$ methane signatures for this sample were plotted graphically to determine the potential origin (Figure 16). The groundwater at this site is type $\mathrm{Ca}-\mathrm{HCO}_{3}$ type, the most common water type in the region. McPhillips et al. (2014) found methane concentrations in the $\mathrm{Ca}-\mathrm{HCO}_{3}$ groundwater type to be statistically different from $\mathrm{Na}-\mathrm{HCO} / 3 / \mathrm{Cl}$ water types, with the latter having the majority of methane concentration exceeding $1 \mathrm{mg} / \mathrm{L}$. Methane concentrations at these levels have seldom been found in $\mathrm{Ca}-\mathrm{HCO}_{3}$ waters (Molofsky et al., 2013; McPhillips et al., 2014). The relationship between $\mathrm{Na}-\mathrm{Cl}$ waters and methane have been linked to deep brines and potential upward migration (Molofsky et al., 2013; McPhillips et al., 2014; Warner et al., 2012). However, this relationship is not seen in the current study, likely because the isotope ratios indicate the methane is from a shallow, biogenic origin.

\section{Implications and Conclusion}

This study investigated baseline geochemistry of groundwater in a region of the Appalachian plateaus province in West Virginia with little land use and oil and gas development. Focusing mostly on the local and intermediate groundwater flow systems that are used by residents and public networks, this baseline characterization has shown that the major control on groundwater composition is water-rock interaction and increased mineralization along the groundwater flow network. Deep groundwater chemistry, typically found at valley settings, is geochemically different from shallow chemistry, that is typically found at hilltop settings. Silicate weathering is the dominant process occurring at depth and carbonate dissolution is the dominant process in shallow environments. The research area has also been influenced by iron and manganese due to the presence of coal lithology- specifically 
pyrite and siderite minerals, however, dissolved concentrations are fairly low. Due to the undisturbed nature of the study landscape, the overall mean hydrogeochemistry has not varied temporally. Further, the heterogeneity of cyclothemic sequences prevents spatial relationships in hydrogeochemistry to be inferred.

Moreover, due to the subsurface heterogeneity from sequential cyclothem lithology and fractured bedrock, individual well chemistry remains unique. Although local variations exist, we postulate that in the undisturbed landscape, the relationships found between mineralization and topographic location in the flow network can predict the dominant ions present at similar locations throughout the Appalachian plateau region where the majority of current Marcellus development is ongoing. The knowledge of geochemical trends in an undisturbed region also provides important background information on water quality in the event of future development scenarios. As natural gas development continues to be explored, an understanding of these controls on major-ion chemistry is necessary for interpretation of the hydrogeochemical framework in the region. Though no new development has yet been scheduled, the study area may undergo natural gas development in the near future as infrastructure is put in place. Often, natural gas well pads are positioned on hilltops, where principal recharge occurs. In the event of a spill or leak, drinking water resources in the Monongahela National Forest may incur lasting damage as waters down-gradient of the recharge zones, encompassing a large majority of the flow network, have potential to be affected. Further, the prevalence of pristine, low TDS waters in the study region create a vulnerable landscape where a small disturbance in the natural order could cause notable chemical impacts. Overall, the study region includes private residences, forest operations, recreation facilities and public businesses that rely on private, well water for survival, all who benefit from detailed baseline knowledge of their valuable resource. 
Table 1: Recommended chemistry parameters for private well testing in areas of Marcellus development, parameters are tiered based on vulnerability to change and cost to landowners

\begin{tabular}{|c|c|c|c|c|c|}
\hline \multirow[b]{2}{*}{ Parameter } & \multicolumn{5}{|c|}{ Resource } \\
\hline & WRI & NY DEC & PA DEP & PSU & NGWA \\
\hline Methane & 1 & 1 & 1 & 1 & 1 \\
\hline Total Dissolved Solids (TDS) & 1 & 1 & 1 & 1 & 1 \\
\hline Chloride & 1 & 1 & 2 & 1 & 1 \\
\hline Sodium & 1 & 1 & 1 & 2 & 1 \\
\hline $\mathrm{pH}$ & 1 & 1 & 1 & 1 & 1 \\
\hline Barium & 1 & 1 & 2 & 1 & 1 \\
\hline Iron \& Manganese & 1 & 1 & 1 & 2 & 1 \\
\hline Bromide & $1^{*}$ & & & & 1 \\
\hline Total Suspended Solids (TSS) & 2 & & 2 & 2 & 1 \\
\hline (Specific) Conductivity & 2 & 1 & 2 & & 1 \\
\hline Potassium & 2 & & 2 & & 1 \\
\hline Sulfate & 2 & & 2 & 2 & 1 \\
\hline Calcium & 2 & & 2 & & 1 \\
\hline Alkalinity & 2 & & 2 & 2 & 1 \\
\hline $\begin{array}{l}\text { Volatile Organic Compounds } \\
\text { (VOC - including BTEX) }\end{array}$ & 2 & 1 & & 3 & 1 \\
\hline Hardness & 3 & & 2 & 2 & \\
\hline Ethane & 3 & 1 & 1 & & \\
\hline Oil \& Grease & 3 & & 2 & 2 & 1 \\
\hline Gross alpha & 3 & 1 & & 3 & \\
\hline Gross beta & 3 & 1 & & & \\
\hline Strontium & 3 & & 2 & 2 & \\
\hline Magnesium & 3 & & 2 & & 1 \\
\hline Arsenic & 3 & & & 2 & 1 \\
\hline Surfactants & 3 & & & 2 & \\
\hline Coliform Bacteria & 3 & & 2 & 2 & \\
\hline Static Water Level & 3 & 1 & & & \\
\hline
\end{tabular}


Table 2: Groundwater chemistry and field parameters for the 48 samples in the Gauley River Basin, Monongahela National Forest, West Virginia

\begin{tabular}{|c|c|c|c|c|c|c|c|c|c|c|c|c|c|c|c|c|c|c|}
\hline Number & Sample ID & $\begin{array}{l}\text { Temp. } \\
\text { (C) }\end{array}$ & $\begin{array}{c}\text { SC } \\
\mathrm{uS} / \mathrm{cm}\end{array}$ & $\begin{array}{c}\text { Well Depth } \\
\text { (meter) }\end{array}$ & $\begin{array}{l}\text { Land } \\
\text { Elevation } \\
\text { (meter) }\end{array}$ & $\mathrm{pH}$ & TDS & $\begin{array}{c}\mathrm{Cl} \\
(\mathrm{mg} / \mathrm{L})\end{array}$ & $\begin{array}{c}\mathbf{F} \\
(\mathrm{mg} / \mathrm{L})\end{array}$ & $\begin{array}{c}\mathrm{NO3} \\
\text { (mg/L) }\end{array}$ & $\begin{array}{c}\mathrm{SO4} \\
(\mathrm{mg} / \mathrm{L})\end{array}$ & $\begin{array}{c}\mathrm{Ca} \\
(\mathrm{mg} / \mathrm{L})\end{array}$ & $\begin{array}{c}\mathrm{Mg} \\
(\mathrm{mg} / \mathrm{L})\end{array}$ & $\begin{array}{c}\mathbf{K} \\
(\mathrm{mg} / \mathrm{L})\end{array}$ & $\underset{(\mathrm{mg} / \mathrm{L})}{\mathrm{Na}}$ & $\begin{array}{l}\mathrm{HCO} 3 \\
(\mathrm{mg} / \mathrm{L})\end{array}$ & $\begin{array}{c}\mathrm{Fe} \\
(\mathrm{mg} / \mathrm{L})\end{array}$ & $\begin{array}{c}\mathrm{Mn} \\
(\mathrm{mg} / \mathrm{L})\end{array}$ \\
\hline 1 & Grb-0186 & 10.5 & 157 & 23.5 & 847.3 & 7.60 & 105 & 1.5 & 0.0 & 0.09 & 2.5 & 19.0 & 2.7 & 1.0 & 9.0 & 10.98 & 0.05 & 0.21 \\
\hline 2 & Grb-0192 & 8.0 & 100 & 42.7 & 1091.2 & 6.40 & 67 & 6.9 & 0.2 & 0.31 & 2.2 & 9.9 & 4.2 & 1.4 & 3.8 & 4.64 & 0.00 & 0.58 \\
\hline 3 & Nic-0081 & 11.0 & 171 & 14.0 & 634.0 & 7.00 & 115 & 0.9 & 0.2 & 0.13 & 0.5 & 6.0 & 1.6 & 1.1 & 29.0 & 35.38 & 5.00 & 0.17 \\
\hline 4 & Nic-0082 & 10.5 & 214 & 18.1 & 640.1 & 7.10 & 143 & 4.2 & 0.3 & 0.04 & 0.7 & 6.8 & 2.3 & 2.0 & 36.0 & 43.92 & 2.30 & 0.09 \\
\hline 5 & Nic-0083 & 11.0 & 193 & 15.7 & 640.1 & 7.10 & 129 & 5.5 & 0.2 & 0.09 & 0.3 & 8.4 & 2.4 & 1.7 & 30.0 & 36.60 & 2.30 & 0.11 \\
\hline 6 & Nic-0084 & 10.5 & 206 & 16.5 & 655.3 & 7.40 & 138 & 7.2 & 0.3 & 0.04 & 0.5 & 9.7 & 2.1 & 1.2 & 32.0 & 39.04 & 0.46 & 0.03 \\
\hline 7 & Nic-0092 & 13.0 & 234 & 22.3 & 603.5 & 7.40 & 157 & 8.4 & 0.4 & 0.02 & 4.6 & 17.0 & 4.0 & 1.6 & 32.0 & 39.04 & 0.14 & 0.08 \\
\hline 8 & Nic-0116 & 13.0 & 94 & 14.9 & 688.8 & 6.50 & 63 & 0.8 & 0.1 & 0.04 & 3.8 & 7.1 & 2.2 & 0.9 & 3.0 & 3.66 & 7.90 & 0.80 \\
\hline 9 & Nic-0117 & 13.0 & 165 & 22.9 & 694.9 & 6.50 & 111 & 1.5 & 0.1 & 0.04 & 6.6 & 16.0 & 5.4 & 2.1 & 4.7 & 5.73 & 4.90 & 0.51 \\
\hline 10 & Nic-0118 & 13.0 & 390 & 18.3 & 658.4 & 8.60 & 261 & 37.0 & 0.5 & 0.04 & 5 & 6.3 & 2.7 & 0.4 & 84.0 & 102.48 & 0.03 & 0.00 \\
\hline 11 & Nic-0120 & 12.0 & 85 & 28.0 & 823.0 & 6.00 & 57 & 1.1 & 0.2 & 0.04 & 10 & 5.2 & 5.3 & 1.4 & 0.5 & 0.61 & 1.00 & 0.53 \\
\hline 12 & Nic-0121 & 15.0 & 146 & 18.3 & 731.5 & 6.90 & 98 & 0.6 & 0.1 & 0.04 & 2.3 & 13.0 & 4.4 & 1.5 & 1.4 & 1.71 & 2.60 & 0.29 \\
\hline 13 & Nic-0122 & 12.0 & 80 & 34.7 & 1048.5 & 6.20 & 54 & 1.1 & 0.3 & 0.89 & 5.7 & 4.8 & 4.6 & 1.8 & 0.4 & 0.49 & 0.03 & 0.63 \\
\hline 14 & Nic-0123 & 15.0 & 105 & 121.9 & 932.7 & 6.50 & 70 & 1.1 & 0.05 & 13.00 & 7.2 & 14.0 & 0.8 & 1.1 & 1.4 & 1.71 & 0.06 & 0.01 \\
\hline 15 & Nic-0124 & 12.0 & 83 & 24.4 & 871.7 & 6.00 & 56 & 0.9 & 0.2 & 0.09 & 1.8 & 2.7 & 4.2 & 1.1 & 0.5 & 0.61 & 6.60 & 0.72 \\
\hline 16 & Nic-0128 & 12.0 & 167 & 21.9 & 685.8 & 6.40 & 112 & 3.2 & 0.1 & 0.09 & 3.3 & 20.0 & 4.9 & 1.1 & 2.0 & 2.44 & 1.90 & 0.31 \\
\hline 17 & Web-0167 & 10.0 & 58 & 24.4 & 944.9 & 6.40 & 39 & 0.6 & 0.05 & 0.04 & 3.5 & 3.8 & 0.94 & 0.5 & 0.4 & 0.49 & 3.80 & 0.30 \\
\hline 18 & Web-0168 & 10.5 & 195 & 17.7 & 768.1 & 7.40 & 131 & 1.6 & 0.2 & 0.04 & 7.2 & 22.0 & 4.1 & 0.4 & 11.0 & 13.42 & 0.06 & 0.07 \\
\hline 19 & Web-0169 & 11.0 & 175 & 19.8 & 762.0 & 7.10 & 117 & 1.4 & 0.3 & 0.04 & 6.1 & 19.0 & 3.0 & 0.6 & 17.0 & 20.74 & 0.39 & 0.16 \\
\hline 20 & Web-0170 & 10.5 & 135 & 18.7 & 774.2 & 6.90 & 90 & 0.6 & 0.1 & 0.35 & 3.5 & 16.0 & 4.0 & 0.6 & 7.1 & 8.66 & 0.05 & 0.05 \\
\hline 21 & Web-0172 & 12.0 & 83 & 24.1 & 896.1 & 6.00 & 56 & 5.0 & 0.1 & 6.20 & 1.4 & 4.0 & 4.3 & 1.2 & 1.2 & 1.46 & 1.20 & 1.00 \\
\hline 22 & Web-0176 & 12.0 & 55 & 30.5 & 749.8 & 5.70 & 37 & 0.8 & 0.05 & 0.09 & 2.6 & 3.0 & 3.5 & 1.2 & 0.5 & 0.61 & 1.70 & 0.35 \\
\hline 23 & Web-0178 & 12.0 & 120 & 59.7 & 749.8 & 6.00 & 80 & 2.5 & 0.1 & 0.27 & 2 & 13.0 & 4.5 & 1.2 & 2.0 & 2.44 & 0.03 & 0.02 \\
\hline 24 & Web-0179 & 12.0 & 250 & 61.0 & 768.1 & 7.20 & 168 & 0.8 & 0.2 & 0.40 & 1.3 & 34.0 & 6.3 & 2.9 & 1.3 & 1.59 & 0.02 & 0.03 \\
\hline 25 & Web-0180 & 11.5 & 155 & 23.2 & 640.1 & 6.80 & 104 & 2.7 & 0.1 & 0 & 0.1 & 19.0 & 2.7 & 1.7 & 8.4 & 10.25 & 0.01 & 0.10 \\
\hline 26 & Web-0181 & 12.0 & 185 & 14.6 & 676.7 & 6.30 & 124 & 22.0 & 0.05 & 0.49 & 4.3 & 9.5 & 3.2 & 1.1 & 9.5 & 11.59 & 16.00 & 0.50 \\
\hline 27 & Web-0182 & 12.0 & 235 & 41.8 & 707.1 & 6.20 & 157 & 35.0 & 0.05 & 0.09 & 2.3 & 24.0 & 6.1 & 2.2 & 3.2 & 3.90 & 0.96 & 0.08 \\
\hline 28 & Nic-WV01 & 13.1 & 168 & 15.2 & - & 6.39 & 113 & 13.37 & 0.15 & 0.62 & 7.06 & 8.34 & 3.25 & 1.3 & 3.15 & 32.90 & 22.91 & 1.26 \\
\hline 29 & Web-WV02 & 14.6 & 89 & 67.1 & - & 6.10 & 60 & 2.08 & 0.16 & 0.46 & 2.68 & 8.94 & 3.78 & 1.49 & 0.50 & 34.40 & 0.14 & 0.09 \\
\hline 30 & Nic-WV03 & 16.1 & 135 & 25.9 & 900.4 & 6.14 & 90 & 2.19 & 0.22 & 0.12 & 12.6 & 9.35 & 8.47 & 2.73 & 0.96 & 48.30 & 0.01 & 0.42 \\
\hline 31 & Nic-WV05 & 12.6 & 116 & 38.1 & 928.1 & 5.54 & 78 & 3.42 & 0.09 & 1.91 & 18.5 & 9.03 & 3.36 & 2.75 & 1.63 & 25.60 & 0.86 & 0.66 \\
\hline 32 & Nic-WV06 & 11.1 & 95 & 29.3 & 932.7 & 4.90 & 64 & 17.39 & 0.04 & 1.79 & 4.57 & 2.46 & 3.02 & 1.18 & 2.50 & 2.10 & 3.51 & 0.71 \\
\hline 33 & Nic-WV07* & 11.6 & 181 & 24.4 & 637.3 & 7.11 & 121 & 1.52 & 0.50 & 0.27 & 3.01 & 5.41 & 1.57 & 1.10 & 29.28 & 90.90 & 4.23 & 0.13 \\
\hline 34 & Nic-WV08 & 12.9 & 249 & 18.9 & 771.4 & 6.79 & 167 & 5.03 & 0.48 & 0.02 & 17.2 & 10.19 & 2.41 & 1.69 & 32.99 & 115.00 & 8.08 & 0.13 \\
\hline 35 & Web-WV09 & 12.9 & 585 & 39.6 & 696.5 & 8.69 & 392 & 56.17 & 0.80 & 0.66 & 1.87 & 0.97 & 0.21 & 0.43 & 143.25 & 206.60 & 0.02 & 0.01 \\
\hline 36 & Nic-WV10 & 12.7 & 208 & 91.4 & 917.1 & 7.23 & 139 & 1.44 & 0.15 & 0.20 & 1.76 & 15.09 & 6.15 & 3.11 & 15.72 & 106.20 & 0.01 & 0.07 \\
\hline 37 & Web-WV11 & 12.4 & 389 & 41.1 & 606.2 & 6.74 & 261 & 3.95 & 0.13 & 0.02 & 41.8 & 40.61 & 10.20 & 4.89 & 20.71 & 152.30 & 1.30 & 0.25 \\
\hline 38 & Web-WV12 & 12.3 & 113 & - & 691.0 & 5.53 & 76 & 19.64 & 0.11 & 3.90 & 2.95 & 6.49 & 3.03 & 1.90 & 4.89 & 6.00 & 0.01 & 0.07 \\
\hline 39 & Nic-WV13 & 14.3 & 101 & 1.5 & 688.8 & 5.55 & 68 & 3.42 & 0.04 & 9.58 & 10.1 & 10.55 & 1.24 & 1.80 & 2.41 & 18.50 & 0.01 & 0.01 \\
\hline 40 & Web-WV14 & 15.0 & 87 & 8.2 & 837.6 & 5.64 & 58 & 2.68 & 0.10 & 24.60 & 5.72 & 7.69 & 1.48 & 2.22 & 1.54 & 23.70 & 0.04 & 0.01 \\
\hline 41 & Web-WV15 & 12.9 & 175 & 23.5 & 648.6 & 7.04 & 117 & 1.65 & 0.26 & 0.02 & 1.83 & 24.24 & 4.12 & 1.87 & 4.31 & 96.70 & 1.50 & 0.07 \\
\hline 42 & Web-WV16 & 11.6 & 40 & 83.8 & - & 5.29 & 27 & 1.70 & 0.04 & 0.02 & 7.15 & 2.59 & 1.86 & 1.10 & 0.02 & 6.60 & 0.63 & 0.11 \\
\hline 43 & Nic-WV18 & 12.7 & 24 & 1.5 & 714.1 & 4.34 & 16 & 2.16 & 0.04 & 2.49 & 7.21 & 0.96 & 0.48 & 0.85 & 0.84 & 0.00 & 0.03 & 0.01 \\
\hline 44 & Web-WV19 & 12.3 & 130 & 90.5 & 660.5 & 6.60 & 87 & 1.96 & 0.16 & 1.98 & 6.92 & 15.60 & 5.32 & 2.63 & 2.18 & 86.70 & 0.02 & 0.01 \\
\hline 45 & Nic-WVSP01* & 10.6 & 32 & N/A & 1103.4 & 5.19 & 21 & 1.37 & 0.04 & 3.45 & 4.15 & 1.51 & 0.87 & 0.67 & 0.02 & 0.70 & 0.01 & 0.03 \\
\hline 46 & Nic-WVSP02* & 10.0 & 129 & N/A & 610.5 & 6.27 & 86 & 1.39 & 0.14 & 0.89 & 20.1 & 12.08 & 5.76 & 2.13 & 0.02 & 35.20 & 0.01 & 0.06 \\
\hline 47 & Web-WVSP03* & 12.2 & 111 & $\mathrm{~N} / \mathrm{A}$ & 719.3 & 6.30 & 74 & 20.64 & 0.04 & 1.04 & 2.41 & 4.20 & 1.87 & 0.93 & 8.92 & 5.50 & 0.01 & 0.01 \\
\hline 48 & Web-WVSP05 & 12.3 & 28 & N/A & 719.6 & 5.37 & 19 & 1.31 & 0.04 & 0.73 & 4.42 & 1.18 & 1.27 & 0.75 & 0.02 & 3.00 & 0.03 & 0.01 \\
\hline
\end{tabular}


Table 3: Descriptive statistics for the 48 groundwater samples in the Gauley River Basin, Monongahela National Forest, West Virginia, concentrations in $\mathrm{mg} / \mathrm{L}$

\begin{tabular}{|c|c|c|c|c|c|}
\hline Parameter & MEAN & SD & MIN & MEDIAN & MAX \\
\hline $\mathrm{T}(\mathrm{C})$ & 12.2 & 1.5 & 8.0 & 12.0 & 16.1 \\
\hline $\mathrm{SC}(\mathrm{uS} / \mathrm{cm})$ & 168 & 103 & 24 & 156 & 585 \\
\hline Well Depth (m) & 30.7 & 24.2 & 1.5 & 23.5 & 121.9 \\
\hline Elevation (m) & 765.6 & 125.0 & 603.5 & 740.7 & 1091.2 \\
\hline $\mathrm{pH}$ & 6.60 & 0.85 & 4.34 & 6.55 & 8.69 \\
\hline TDS (mg/L) & 112 & 69 & 16 & 105 & 392 \\
\hline $\mathrm{Cl}$ & 6.4 & 11.6 & 0.6 & 2.2 & 56.2 \\
\hline $\mathrm{F}$ & 0.2 & 0.2 & 0.0 & 0.1 & 0.8 \\
\hline NO3 & 1.7 & 4.6 & 0.0 & 0.1 & 24.6 \\
\hline SO4 & 5.6 & 7.2 & 0.1 & 3.5 & 41.8 \\
\hline $\mathrm{Ca}$ & 12.1 & 8.7 & 1.0 & 9.8 & 40.6 \\
\hline $\mathrm{Mg}$ & 3.6 & 2.1 & 0.2 & 3.4 & 10.2 \\
\hline K & 1.6 & 0.9 & 0.4 & 1.3 & 4.9 \\
\hline $\mathrm{Na}$ & 14.7 & 26.5 & 0.4 & 3.5 & 143.3 \\
\hline $\mathrm{HCO}^{-}$ & 34.4 & 48.4 & 0.0 & 11.3 & 206.6 \\
\hline $\mathrm{Fe}$ & 2.0 & 3.2 & 0.0 & 0.7 & 16.0 \\
\hline $\mathrm{Mn}$ & 0.3 & 0.3 & 0.0 & 0.1 & 1.0 \\
\hline
\end{tabular}


Table 4: Geochemical and physical characteristics of water samples at each topographic setting, using mean concentrations in $\mathrm{mg} / \mathrm{L}$

\begin{tabular}{|c|c|c|c|}
\hline & Hilltop & Hillside & Valley \\
\hline & \multicolumn{3}{|c|}{ concentrations in $\mathrm{mg} / \mathrm{L}$} \\
\hline$n$ (sample count) & 20 & 11 & 17 \\
\hline $\mathrm{pH}$ & 5.90 & 6.48 & 7.13 \\
\hline $\mathrm{Cl}$ & 4.23 & 7.69 & 8.83 \\
\hline $\mathrm{SO}_{4}$ & 5.33 & 8.13 & 4.67 \\
\hline $\mathrm{Ca}$ & 8.37 & 16.15 & 10.93 \\
\hline $\mathrm{Mg}$ & 3.56 & 4.48 & 2.68 \\
\hline $\bar{K}$ & 1.57 & 1.84 & 1.22 \\
\hline $\mathrm{Na}$ & 1.76 & 6.53 & 29.42 \\
\hline $\mathrm{HCO}_{3}$ & 13.23 & 38.18 & 48.04 \\
\hline $\mathrm{Fe}$ & 1.03 & 1.89 & 3.61 \\
\hline $\mathrm{Mn}$ & 0.29 & 0.18 & 0.24 \\
\hline Conductivity (uS/cm) & 100 & 163 & 213 \\
\hline TDS $(\mathrm{mg} / \mathrm{L})$ calculated & 67 & 109 & 143 \\
\hline Well depth (meter) & 44.2 & 34.5 & 18.9 \\
\hline Land elevation (meter) & 863.6 & 709.5 & 694.9 \\
\hline Water type $(n)$ & Ca-Mg-SO ${ }_{4}(11)$ & $\begin{array}{l}\mathrm{Ca}-\mathrm{HCO}_{3}(5) \\
\mathrm{Na}-\mathrm{Ca}-\mathrm{Cl}(4)\end{array}$ & $\mathrm{Na}-\mathrm{Ca}-\mathrm{HCO}_{3}(13)$ \\
\hline
\end{tabular}


Table 5: PCA loadings and proportion of variance for the first three principal components

\begin{tabular}{|r|r|r|r|r|}
\hline & PC1 & PC2 & PC3 & PC4 \\
\hline $\mathrm{pH}$ & -0.451 & 0.191 & -0.197 & 0.119 \\
\hline $\mathrm{Ca}$ & -0.435 & -0.305 & -0.148 & 0.052 \\
\hline $\mathrm{Mg}$ & -0.328 & -0.411 & 0.309 & 0.015 \\
\hline $\mathrm{K}$ & -0.157 & -0.582 & 0.062 & -0.142 \\
\hline $\mathrm{Na}$ & -0.421 & 0.250 & -0.155 & -0.291 \\
\hline $\mathrm{HCO}_{3}$ & -0.463 & 0.048 & -0.117 & 0.252 \\
\hline $\mathrm{Cl}$ & -0.090 & 0.089 & 0.137 & -0.877 \\
\hline $\mathrm{SO}_{4}$ & 0.114 & -0.332 & 0.407 & 0.061 \\
\hline $\mathrm{Fe}$ & -0.136 & 0.339 & 0.488 & 0.203 \\
\hline $\mathrm{Mn}$ & -0.209 & 0.255 & 0.616 & 0.026 \\
\hline & & & & \\
\hline \% Variance & $34.10 \%$ & $51.00 \%$ & $65.20 \%$ & $76.80 \%$ \\
\hline Cumulative Proportion of Variance & 0.341 & 0.510 & 0.652 & 0.768 \\
\hline \multicolumn{3}{|c|}{}
\end{tabular}


Table 6: Geochemical and physical characteristics of each HCA cluster, using mean concentrations in $\mathrm{mg} / \mathrm{L}$

\begin{tabular}{|c|c|c|c|}
\hline & Cluster 1 & Cluster 2 & Cluster 3 \\
\hline & \multicolumn{3}{|c|}{ concentrations in $\mathrm{mg} / \mathrm{L}$} \\
\hline$n$ (sample count) & 7 & 15 & 26 \\
\hline $\mathrm{pH}$ & 5.27 & 6.42 & 6.8 \\
\hline $\mathrm{Cl}$ & 9.17 & 5.69 & 6.53 \\
\hline $\mathrm{SO}_{4}$ & 4.69 & 9.88 & 3.62 \\
\hline $\mathrm{Ca}$ & 2.77 & 13.39 & 11.94 \\
\hline $\mathrm{Mg}$ & 1.77 & 4.50 & 3.32 \\
\hline $\mathrm{K}$ & 1.05 & 2.17 & 1.25 \\
\hline $\mathrm{Na}$ & 2.45 & 12.97 & 15.20 \\
\hline $\mathrm{HCO}_{3}$ & 3.41 & 49.62 & 28.19 \\
\hline $\mathrm{Fe}$ & 0.60 & 0.24 & 3.66 \\
\hline $\mathrm{Mn}$ & 0.13 & 0.19 & 0.311 \\
\hline Conductivity (uS/cm) & 63 & 174 & 168 \\
\hline TDS (mg/L) calculated & 42 & 117 & 113 \\
\hline Well depth (meter) & 38.20 & 50.64 & 21.93 \\
\hline Land elevation (meter) & 813.4 & 797.7 & 736.8 \\
\hline Water type $(n)$ & $\begin{array}{l}\mathrm{Ca}-\mathrm{Mg}-\mathrm{SO} 4(3) \\
\mathrm{Na}-\mathrm{Ca}-\mathrm{Mg}-\mathrm{Cl}(3)\end{array}$ & $\begin{array}{l}\text { Ca-Mg-SO } \\
\text { Ca-Mg- }-\mathrm{HCO}_{3}(7) \\
\end{array}$ & $\begin{array}{l}\mathrm{Na}-\mathrm{Ca}-\mathrm{HCO} 3(15) \\
\mathrm{Ca}-\mathrm{Mg}-\mathrm{SO} 4(7)\end{array}$ \\
\hline Topographic setting & $\begin{array}{l}\text { Hilltop (5) } \\
\text { Hillside (2) }\end{array}$ & $\begin{array}{l}\text { Hilltop (10) } \\
\text { Hillside (3) }\end{array}$ & $\begin{array}{l}\text { Valley (15) } \\
\text { Hillside (6) }\end{array}$ \\
\hline
\end{tabular}


Table 7: Isotopic characteristics of methane at sample sites in the Gauley River Basin, Monongahela National Forest, West Virginia

\begin{tabular}{|l|c|c|c|c|c|}
\hline \multicolumn{1}{|c|}{ ID } & DIC* & $\delta^{13} \mathrm{C}$, methane & $\delta^{13} \mathrm{C}$, ethane & $\delta^{2} \mathrm{H}$, methane & $\delta^{18} \mathrm{O}$, water \\
\hline \multicolumn{5}{|c|}{} & \multicolumn{4}{c|}{ concentrations in per mil, \%o } \\
\hline Web-WV15 & -9.3 & -59.6 & ND & -200.9 & -11.0 \\
\hline Web-WV16 & -9.9 & ND & ND & ND & -10.3 \\
\hline Web-WV19 & -9.5 & ND & ND & ND & -10.7 \\
\hline Nic-WV20 & -9.5 & ND & ND & ND & -10.3 \\
\hline
\end{tabular}




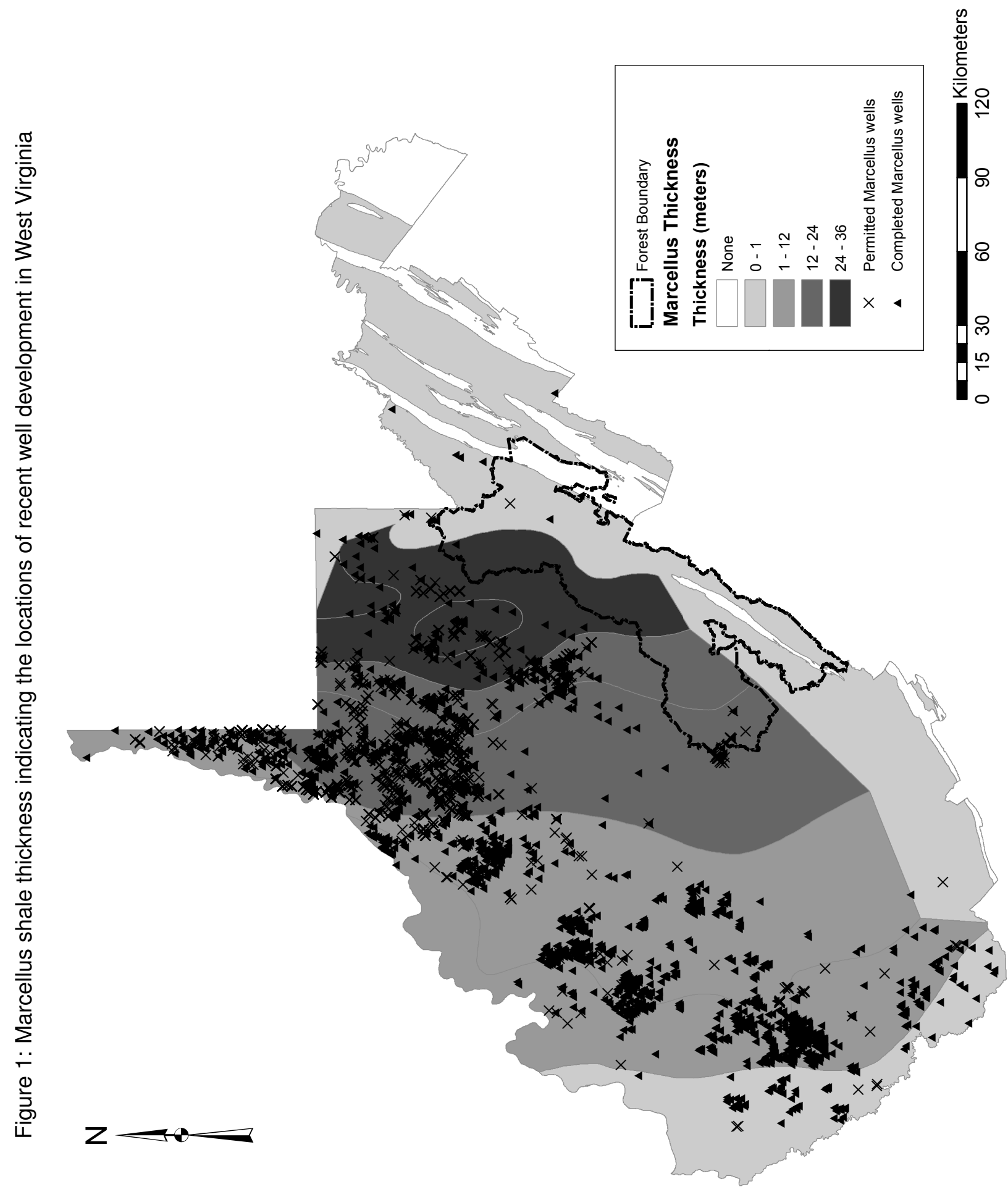

i⿺ 
Figure 2: Historic mine development in the Gauley River Subbasin, (McAuley, 1985)

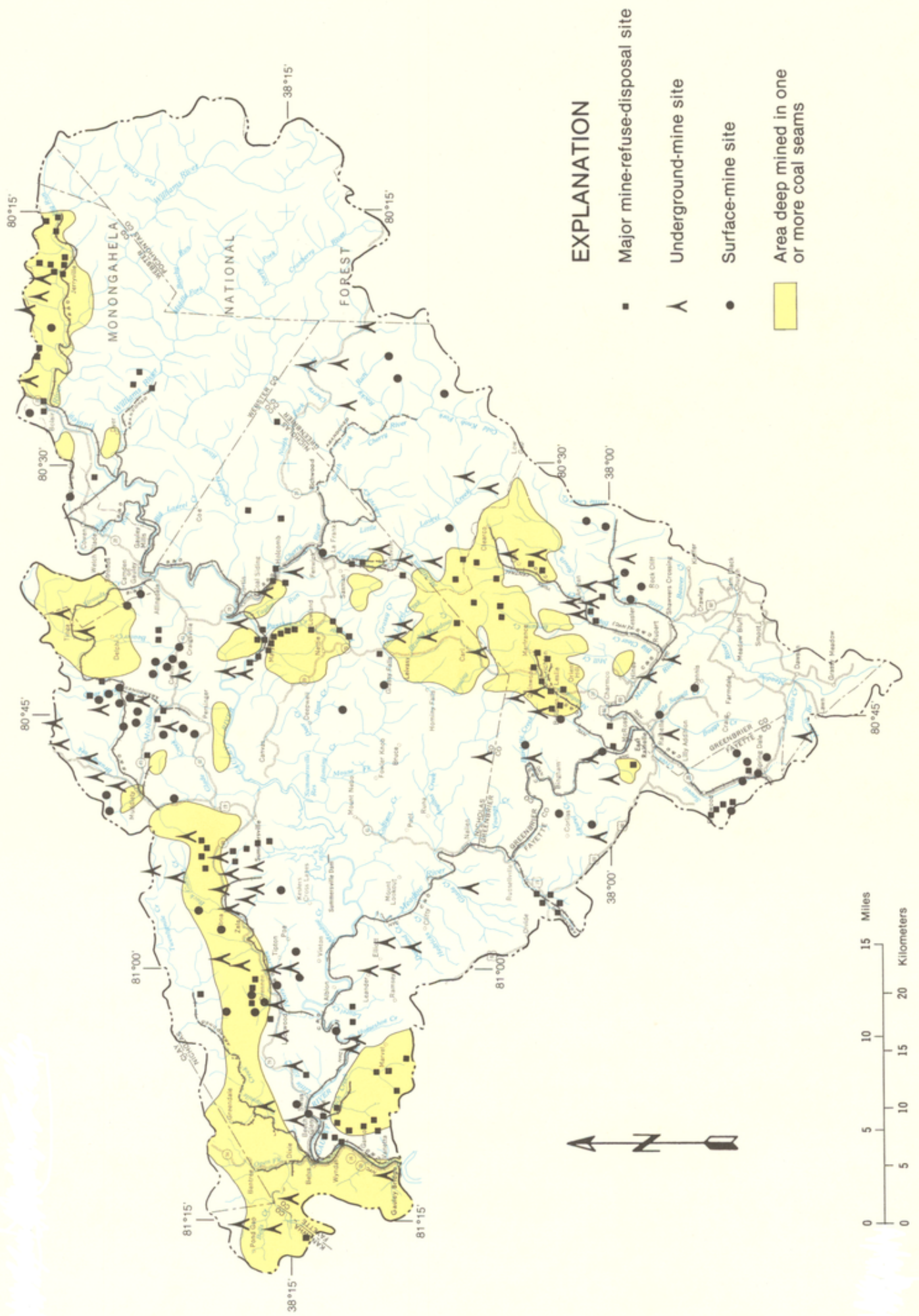




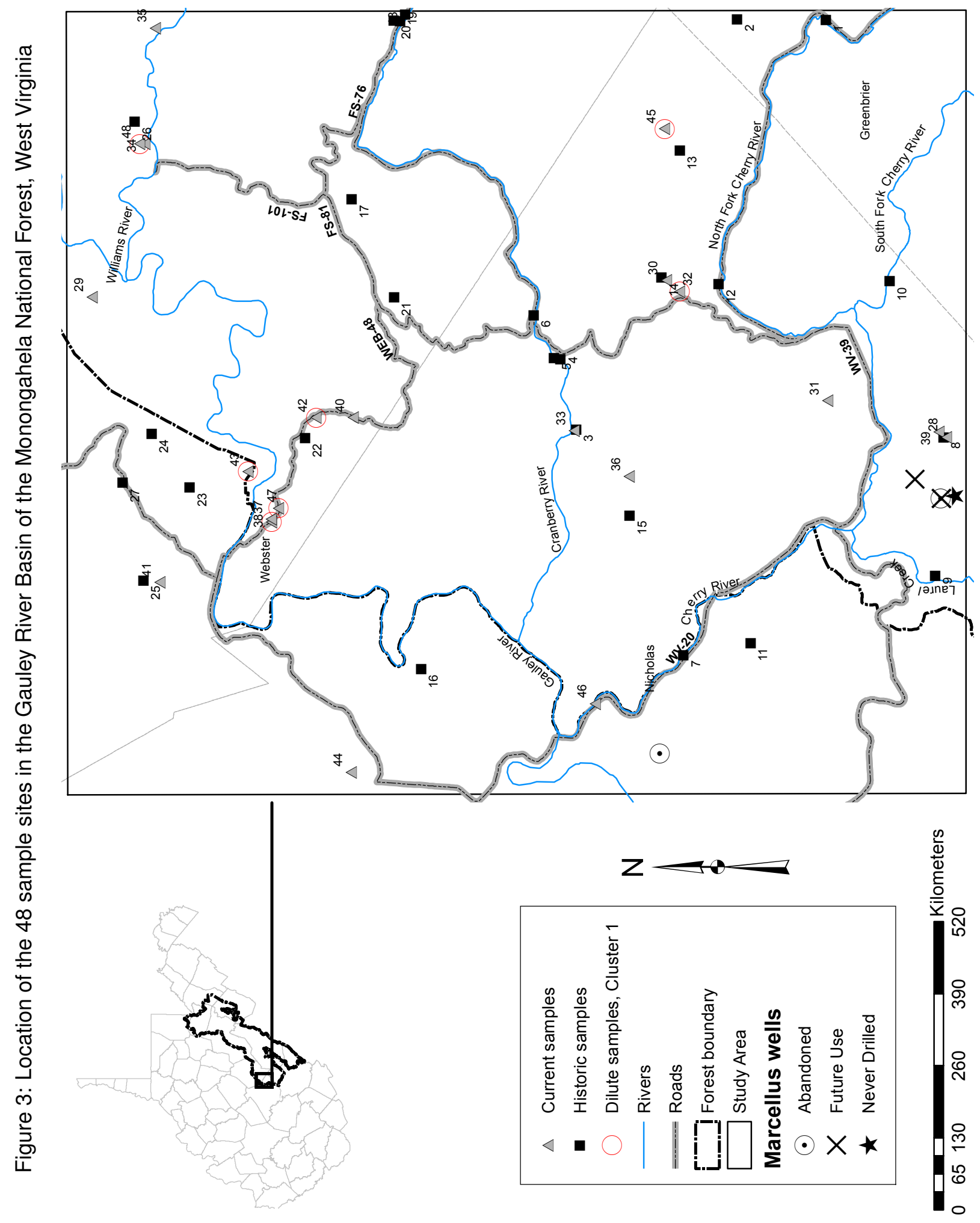




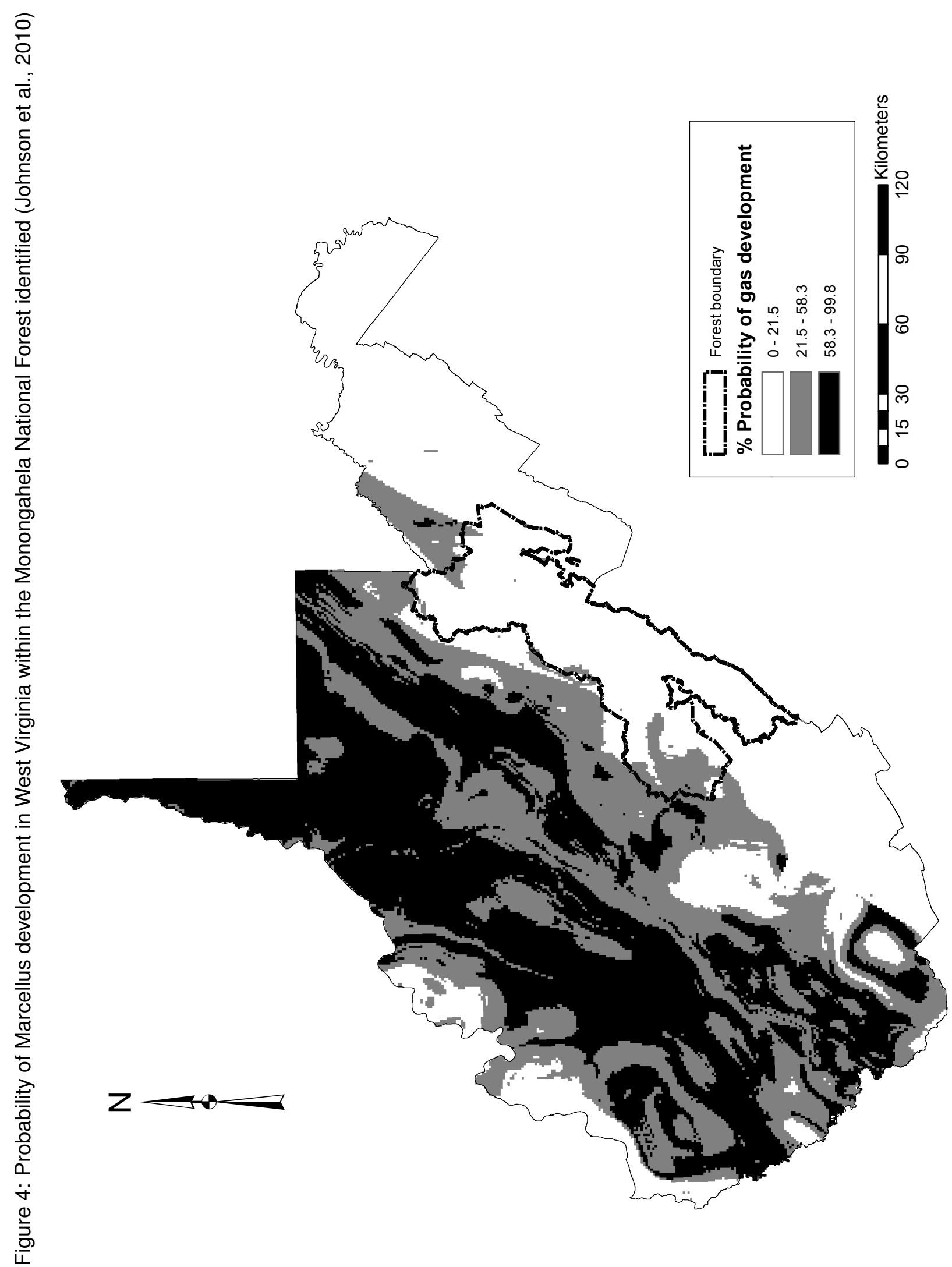




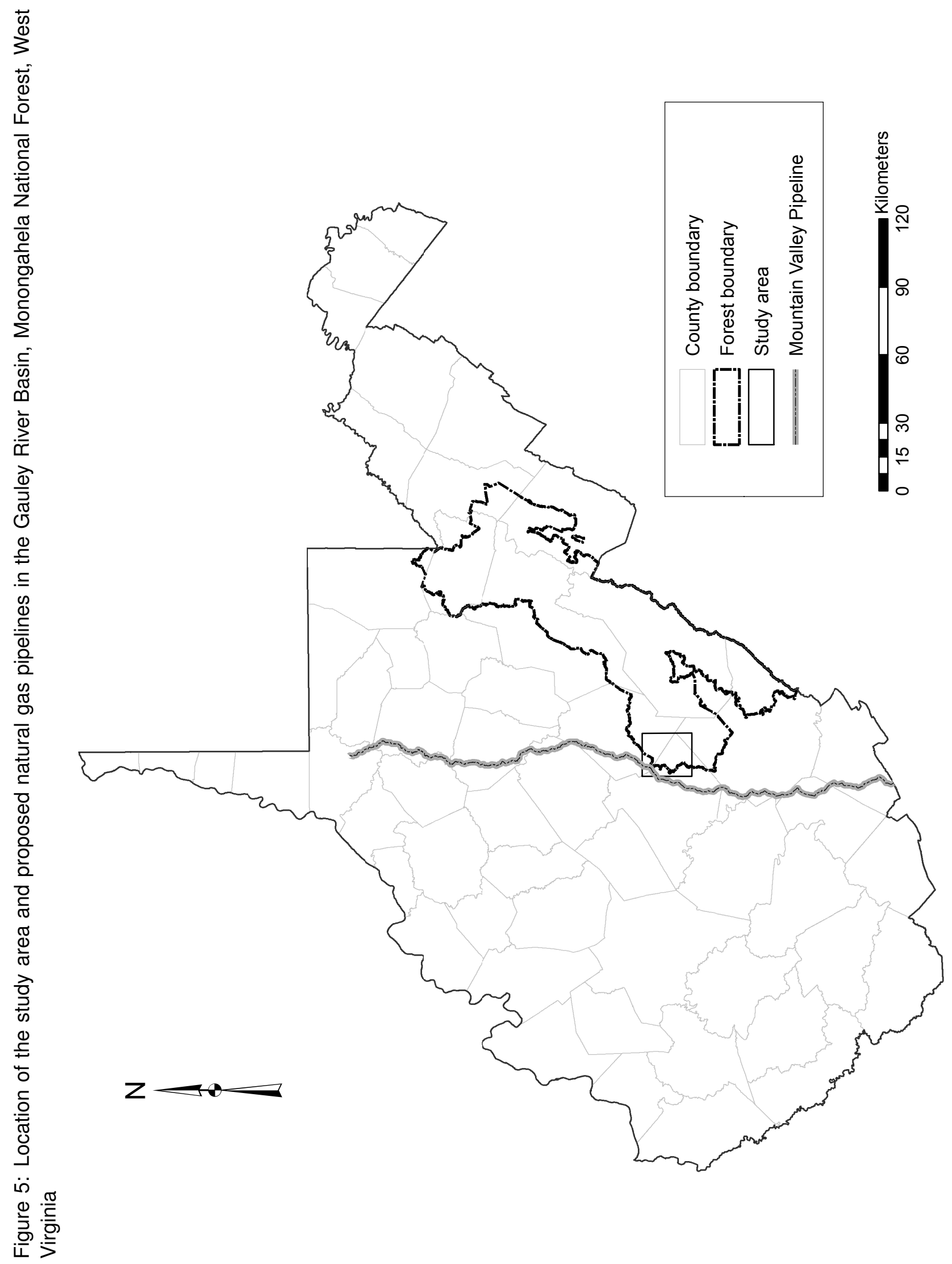


Figure 6: Histogram of Total Dissolved Solids (TDS) for the 48 groundwater samples in the Gauley River Basin, Monongahela National Forest of West Virginia. TDS below $150 \mathrm{mg} / \mathrm{L}$ is most prevalent, indicating ultra fresh samples

Histogram of TDS

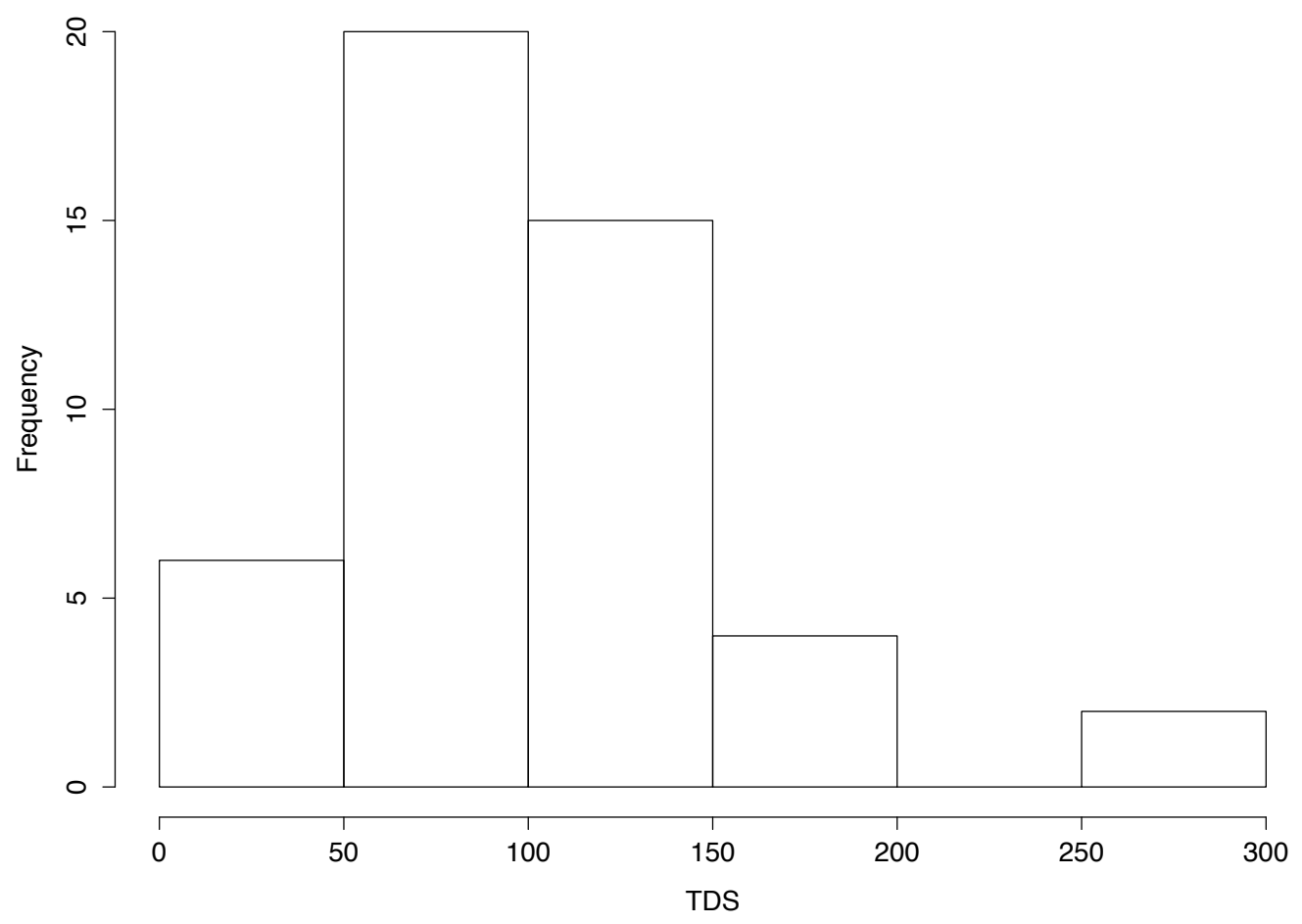


Figure 7: Piper diagram of the 48 groundwater samples in the Gauley River Basin, Monongahela National Forest of West Virginia, labeled according to water type

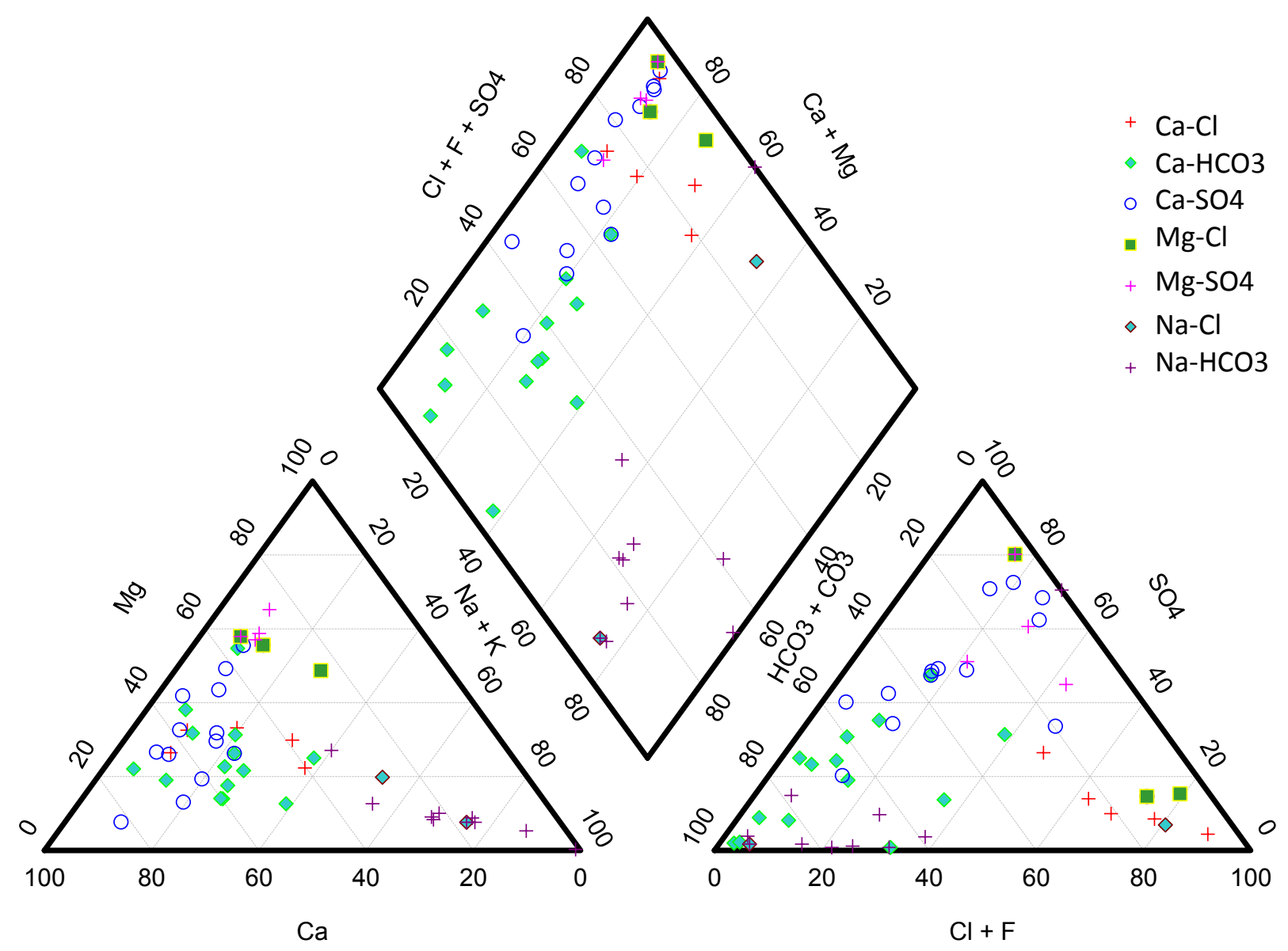




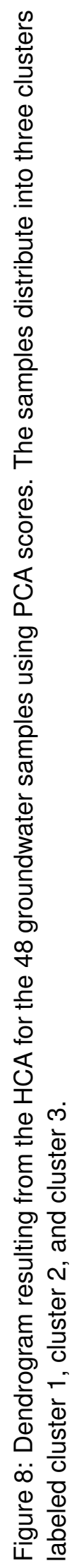

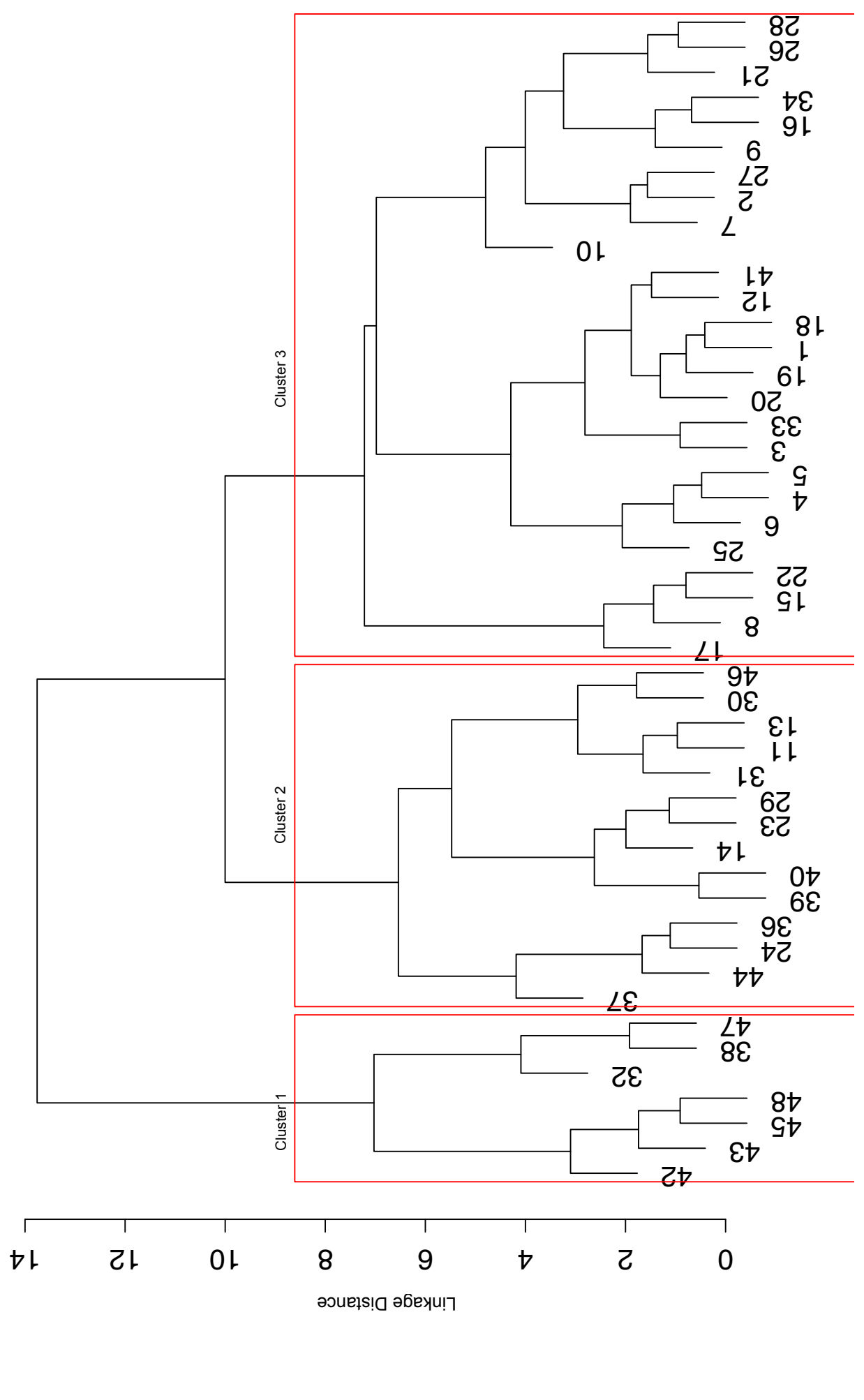




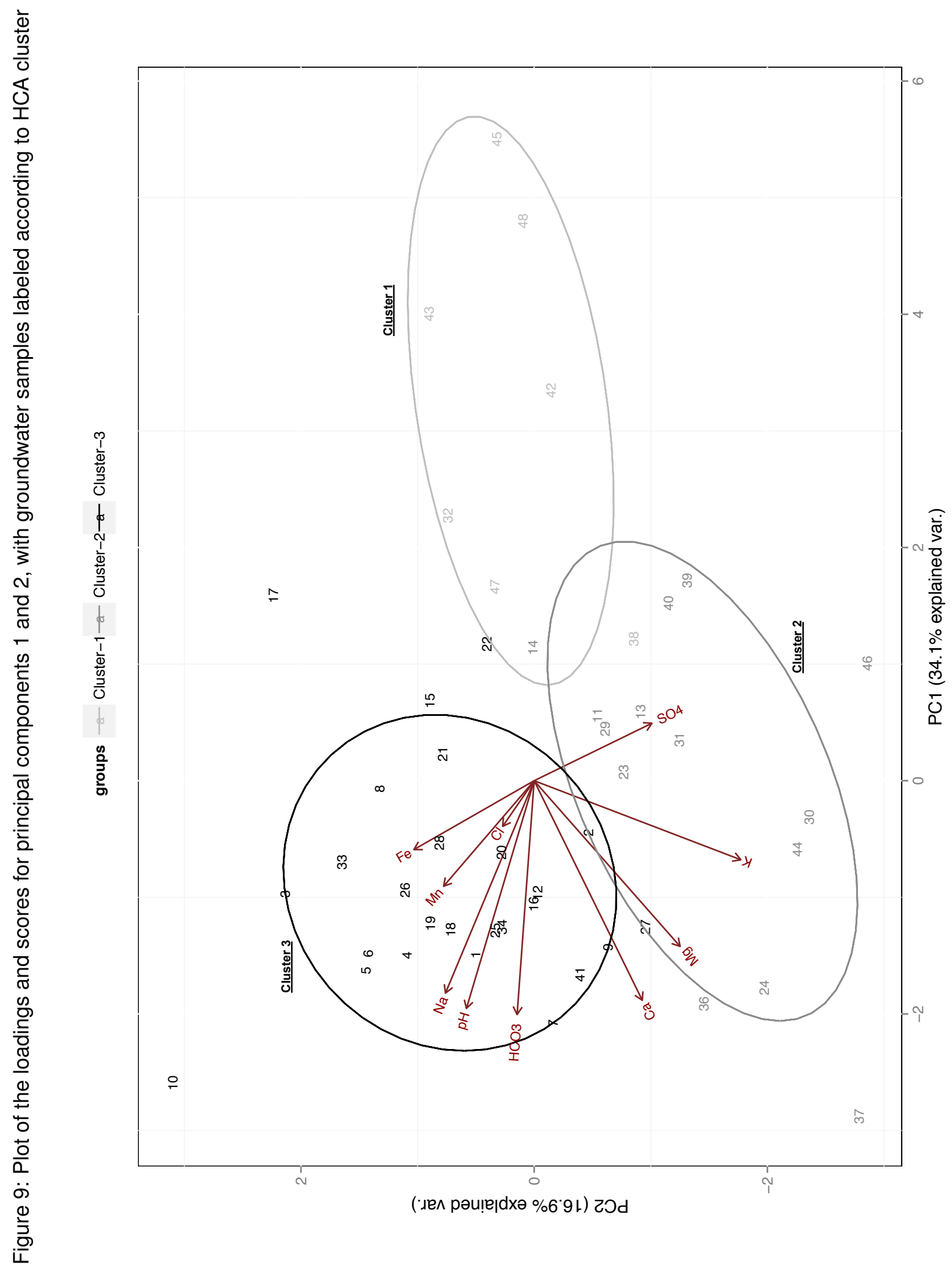


Figure 10: Piper diagram of groundwater samples in the Gauley River Basin, Monongahela National Forest in West Virginia, grouped according to HCA cluster

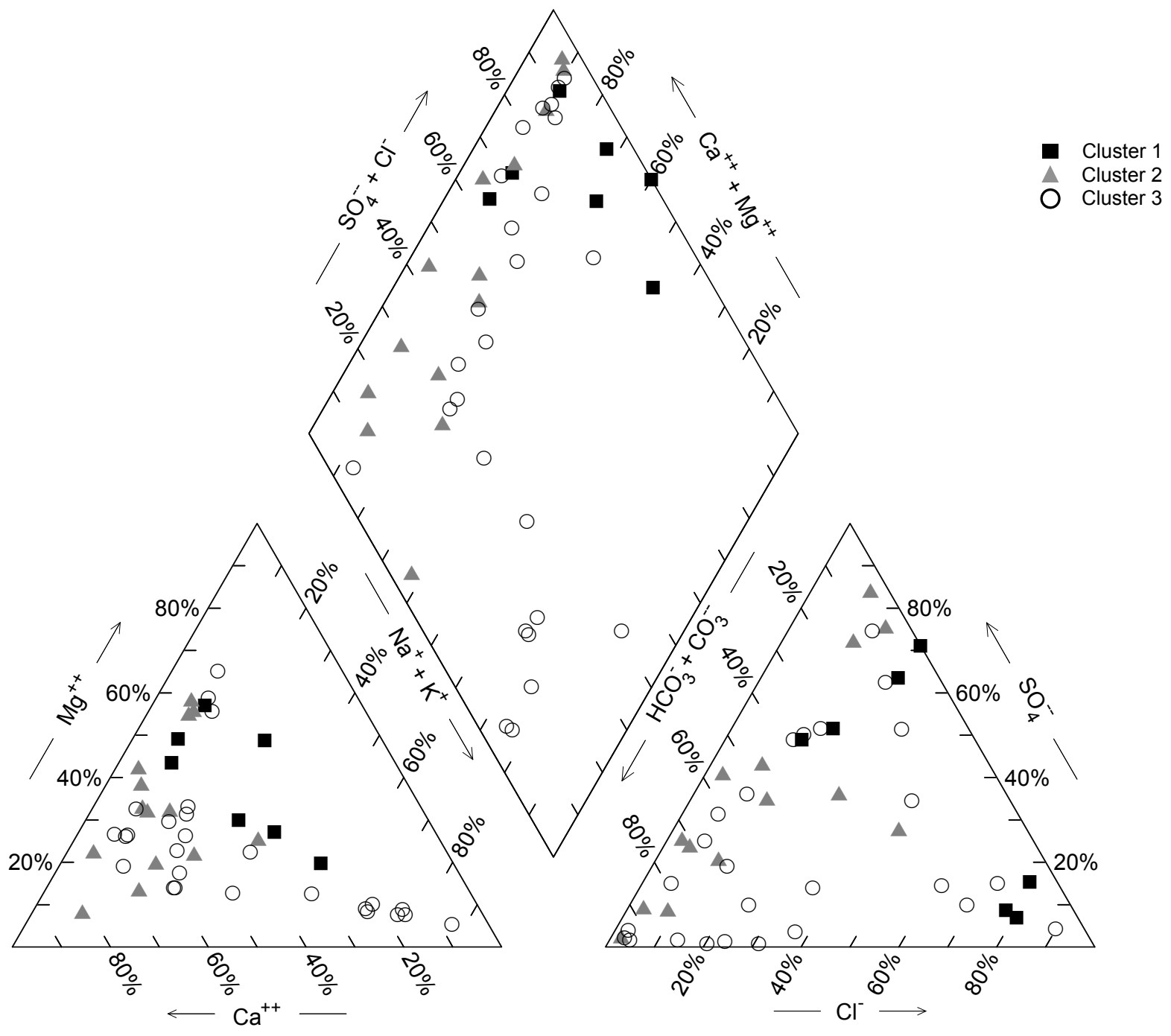



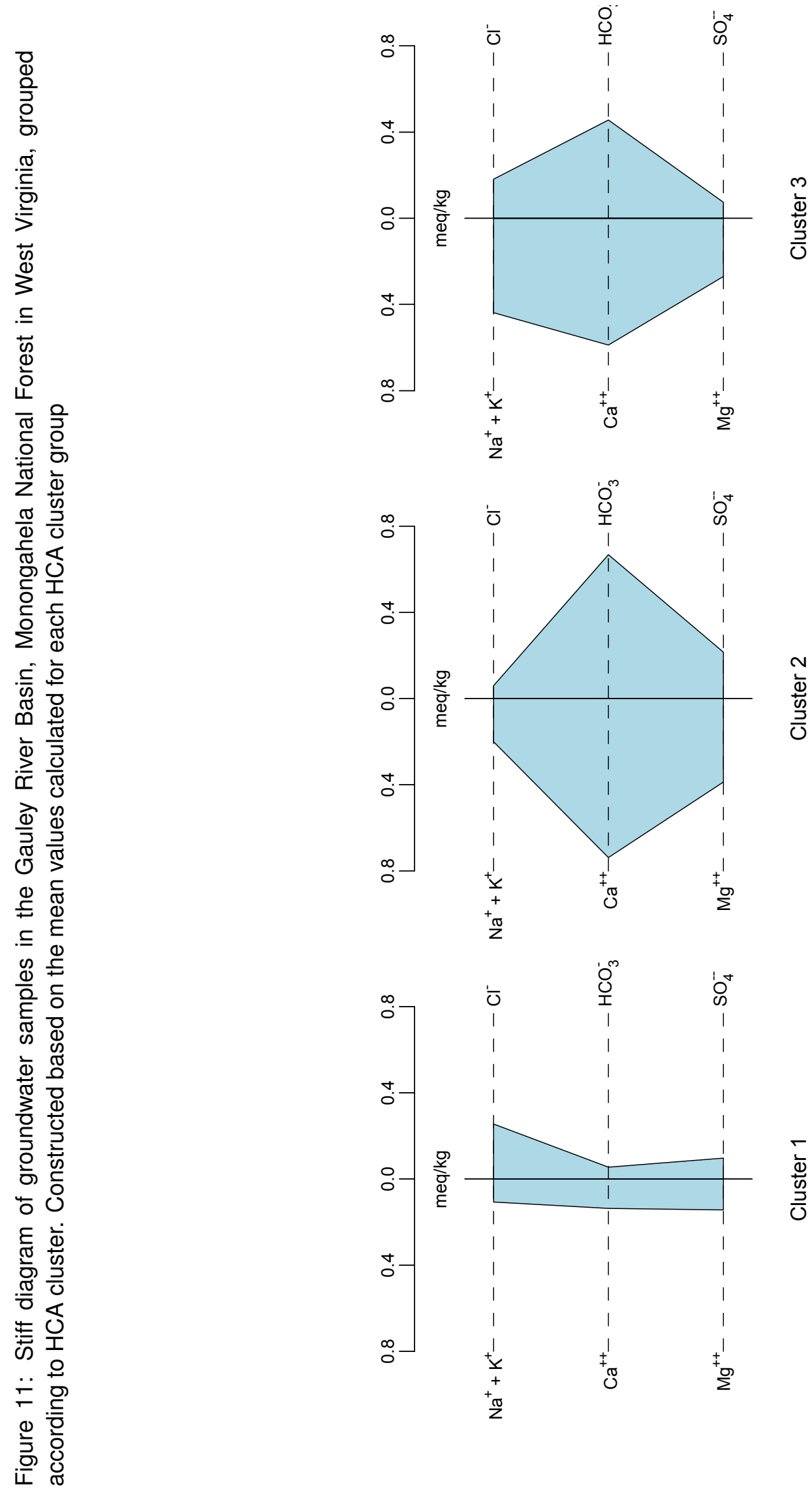
Figure 12: Piper diagram of groundwater samples grouped according to topographic setting

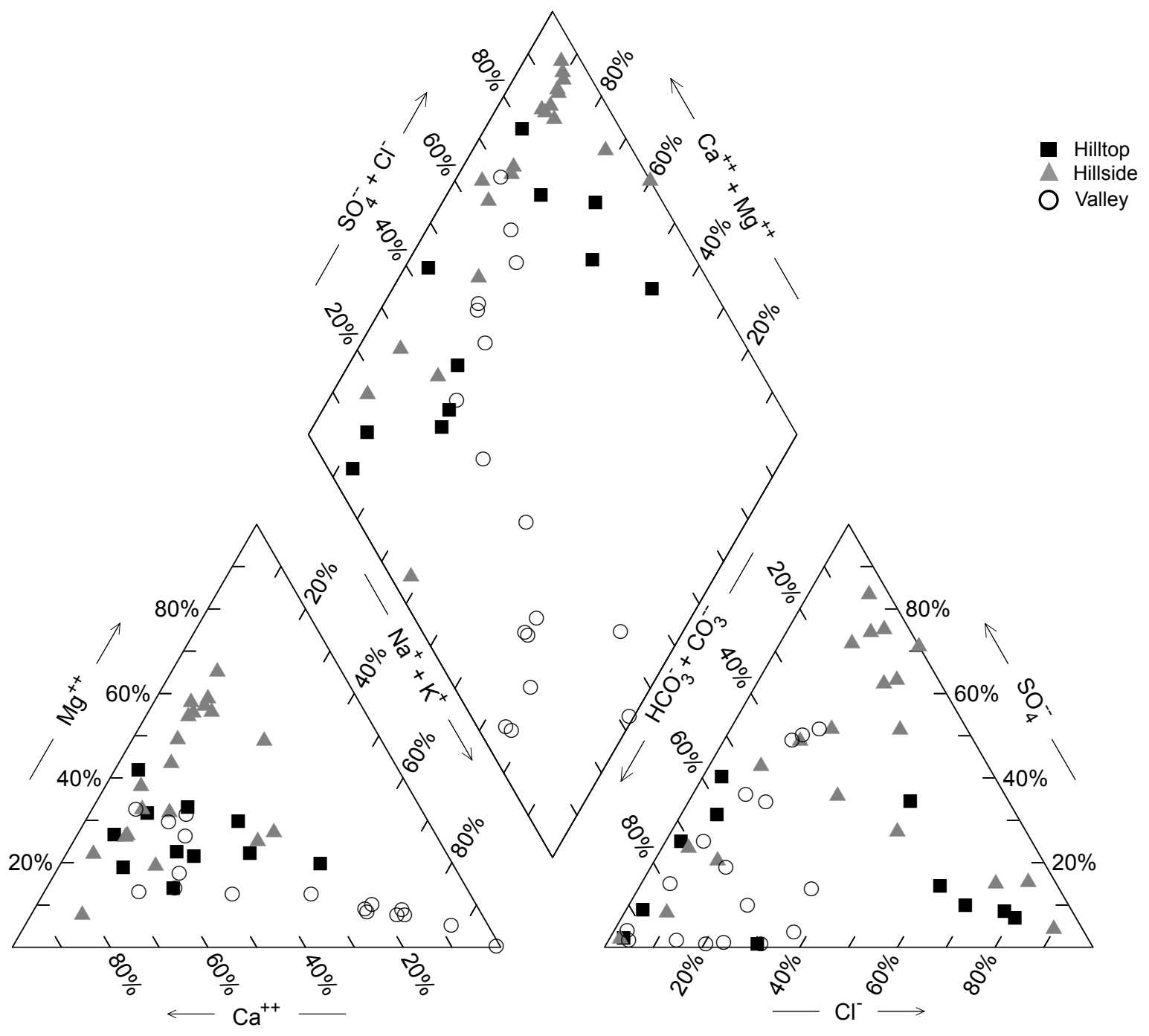



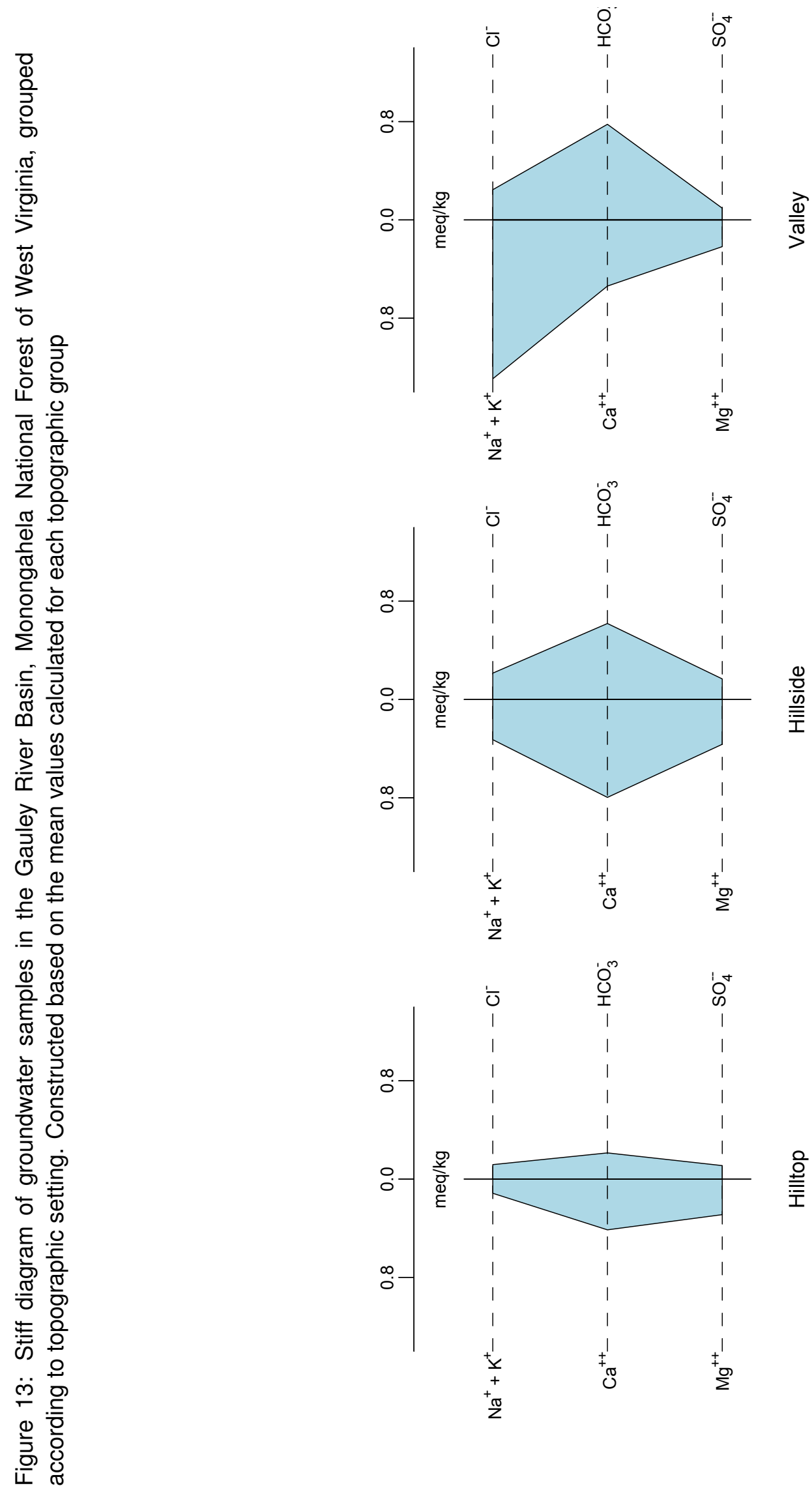
Figure 14: Gibbs diagram plotting the TDS as a function of the $\mathrm{Cl} / \mathrm{Cl}_{+} \mathrm{HCO}_{3}{ }^{-}$ratio. Samples are labeled according to HCA cluster and dominant processes are determined.

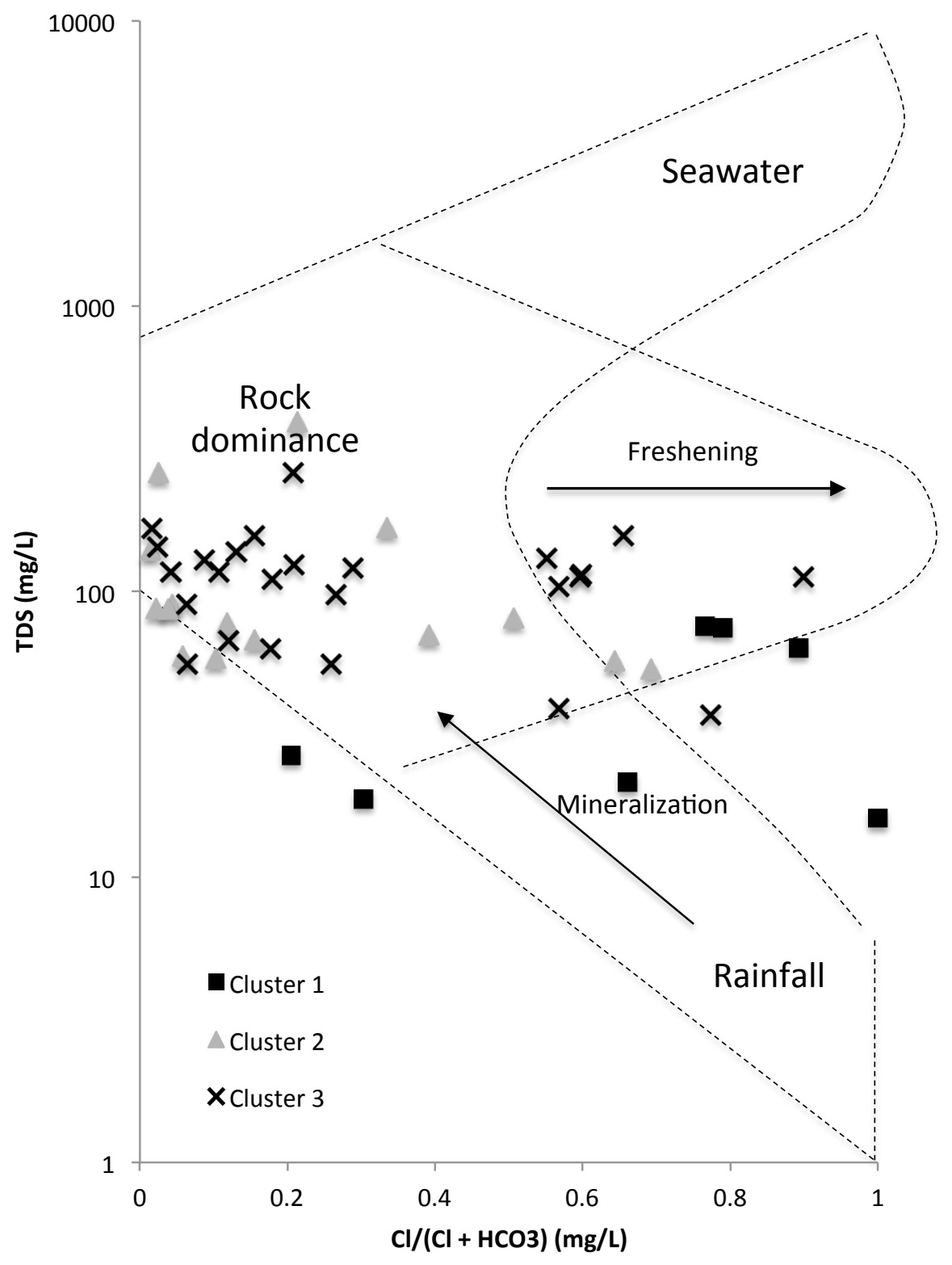


Figure 15: Gibbs diagram plotting the TDS as a function of the $\mathrm{Cl} / \mathrm{Cl}_{+} \mathrm{HCO}_{3}{ }^{-}$ratio. Samples are labeled according to topographic setting and dominant processes are determined.

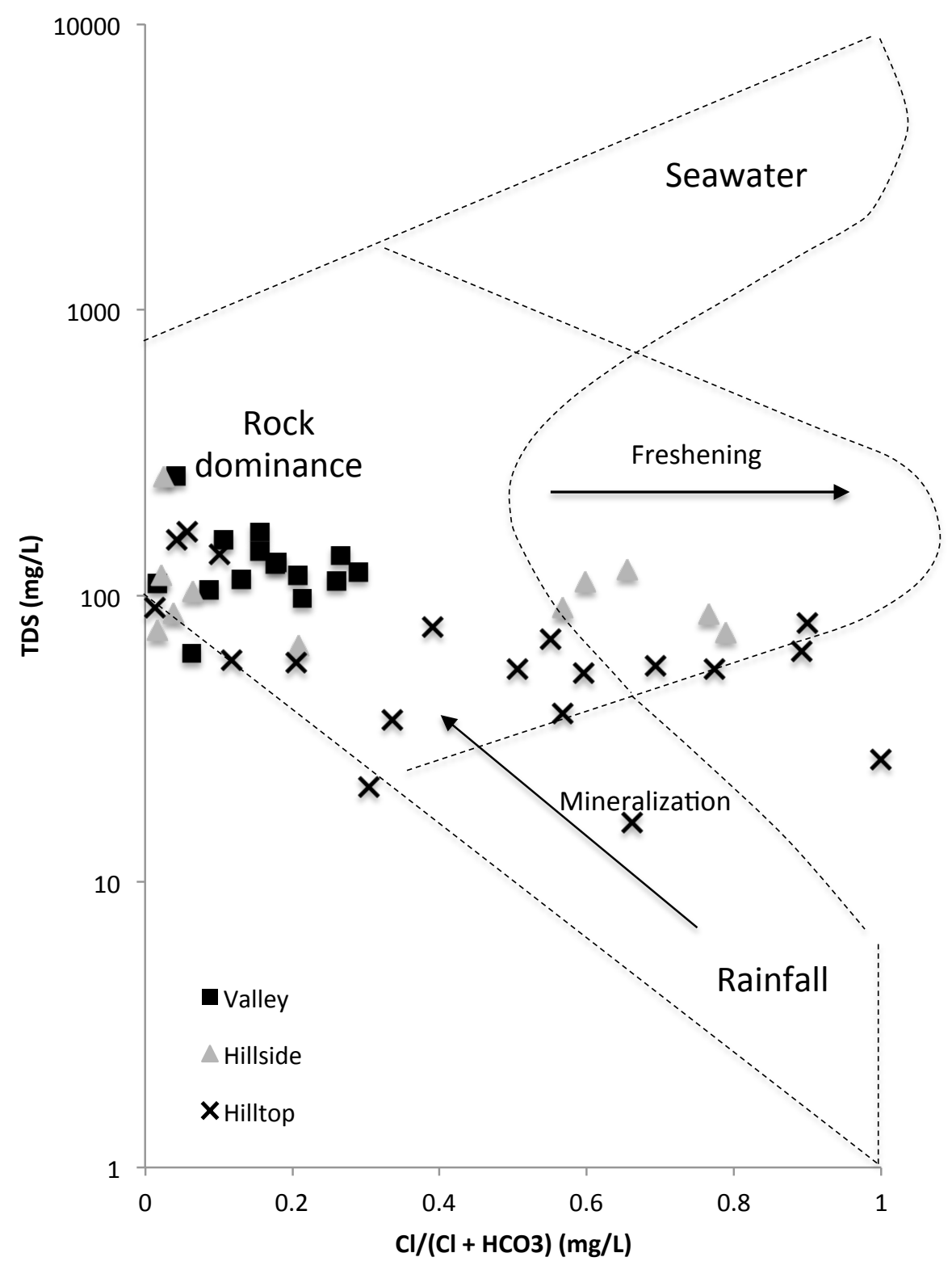


Figure 16: Plot of ${ }^{13} \mathrm{C}-\mathrm{CH}_{4}$ versus ${ }^{2} \mathrm{H}-\mathrm{CH}_{4}$, used to determine the origin of methane one sample with detectable methane (Web-WV15) in the Gauley River Basin, Monongahela National Forest in West Virginia.

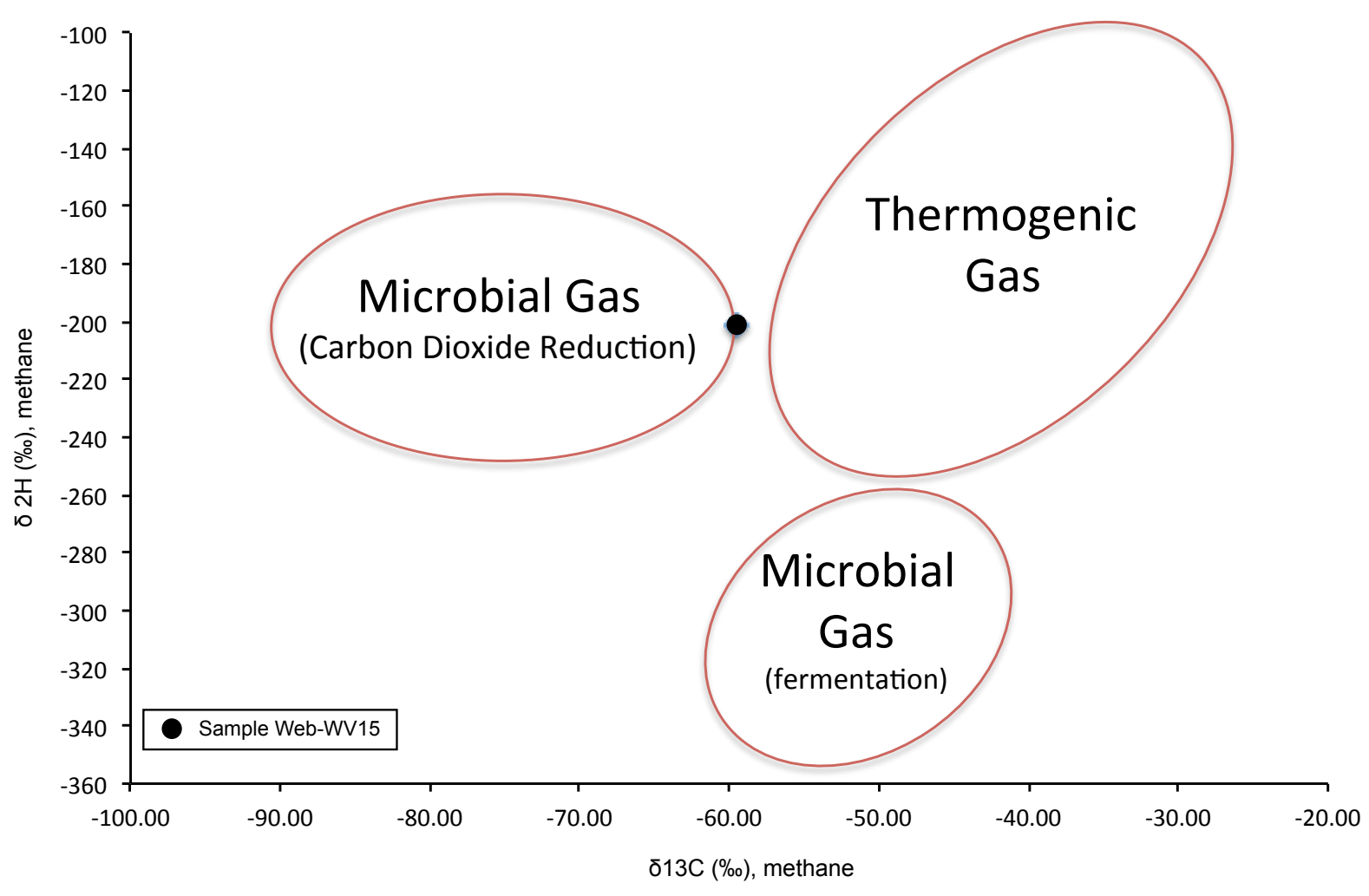


Figure 17: Relation between $\mathrm{Na}$ and $\mathrm{Cl}$, with groundwater samples labeled according to $\mathrm{HCA}$ cluster

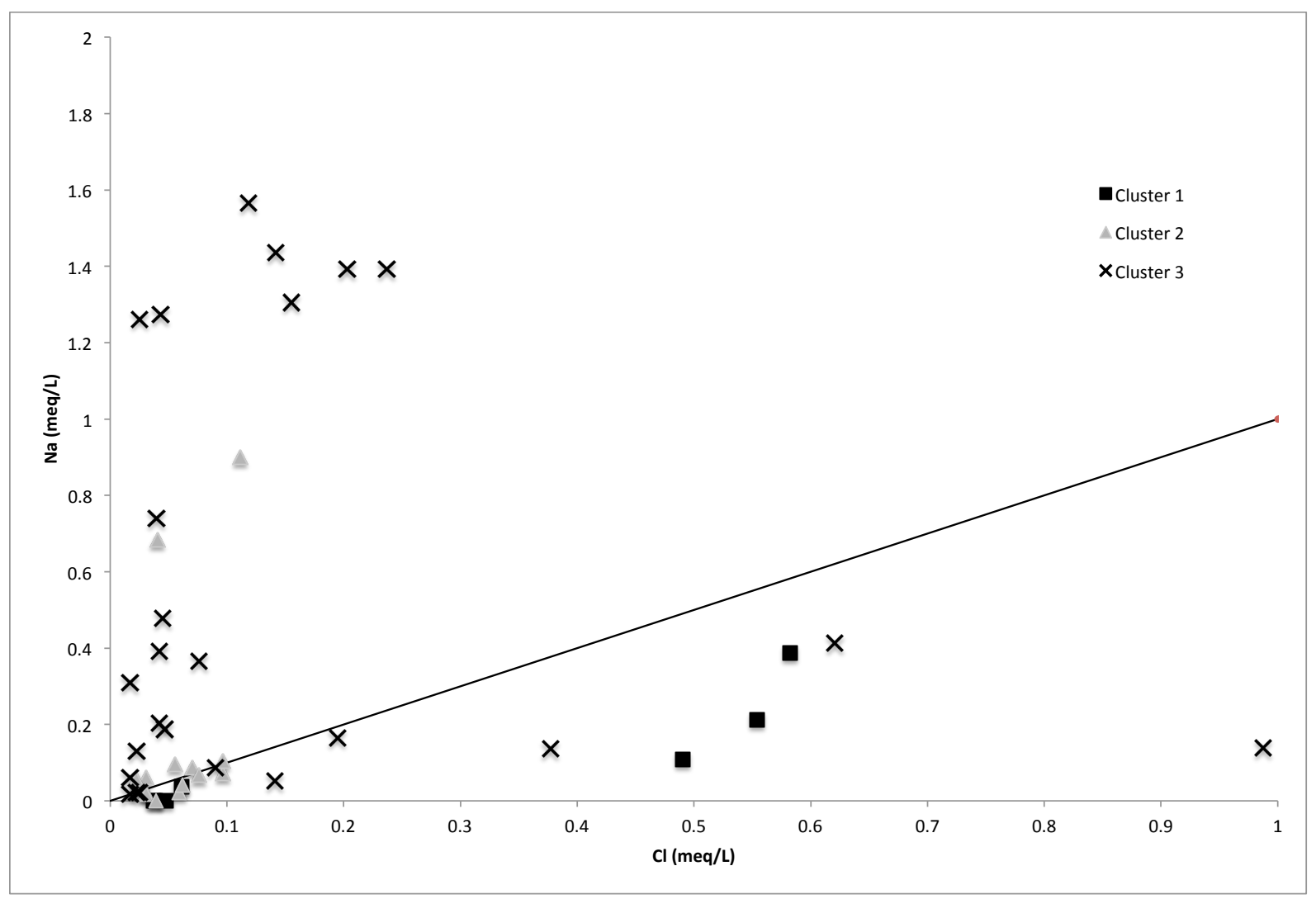


Figure 18: Stability field diagram of the $\mathrm{K}_{2} \mathrm{O}-\mathrm{Al}_{2} \mathrm{O}_{3}-\mathrm{SiO}_{2}-\mathrm{H}_{2} \mathrm{O}$ system, showing the chemical composition of groundwater samples, labeled according to HCA cluster

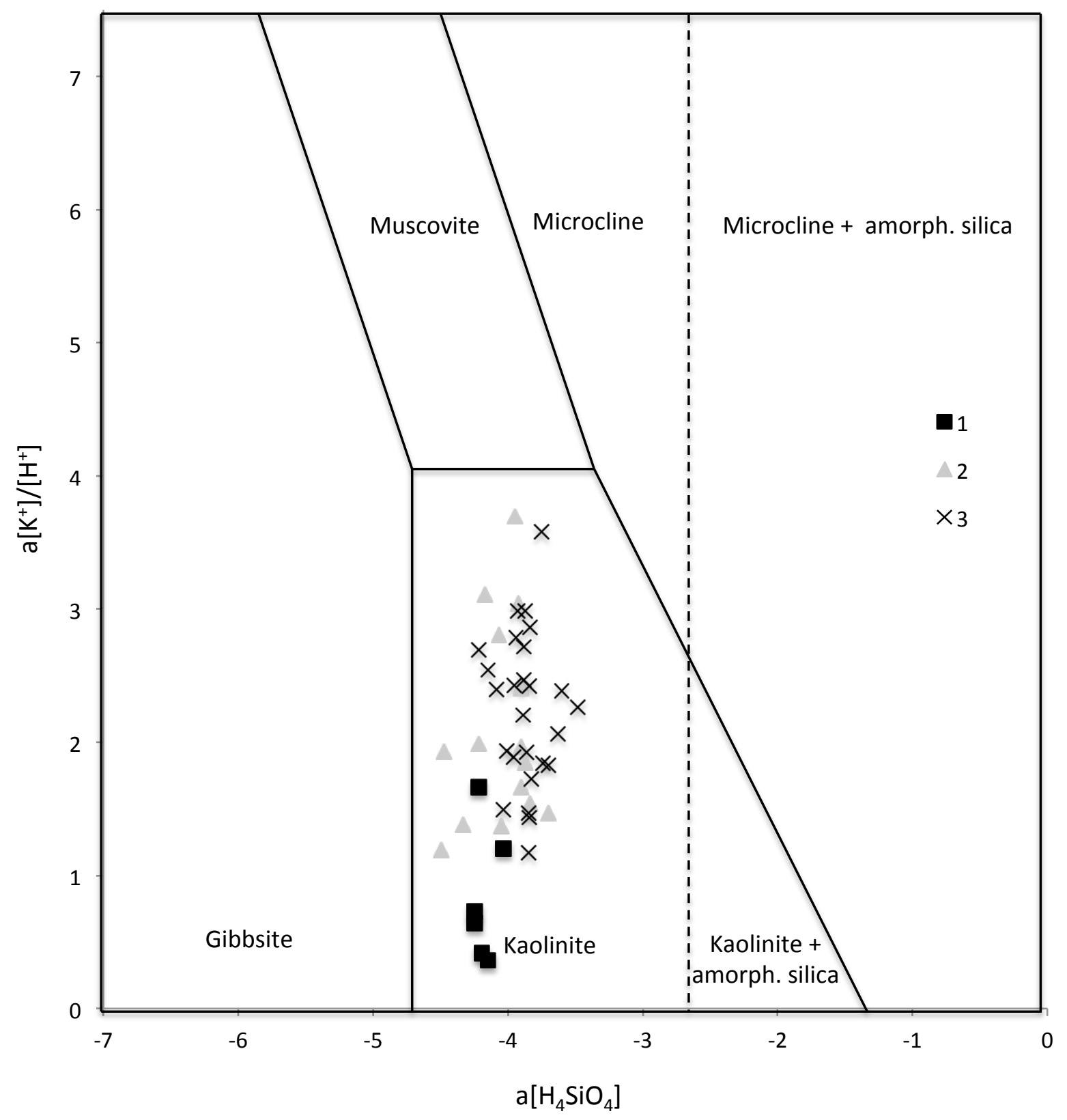


Figure 19: Relation between $\mathrm{Na}-\mathrm{Cl}$ and $\mathrm{Ca}+\mathrm{Mg}_{-} \mathrm{SO}_{4}-\mathrm{HCO}_{3}{ }^{-}$, with groundwater samples labeled according to HCA cluster

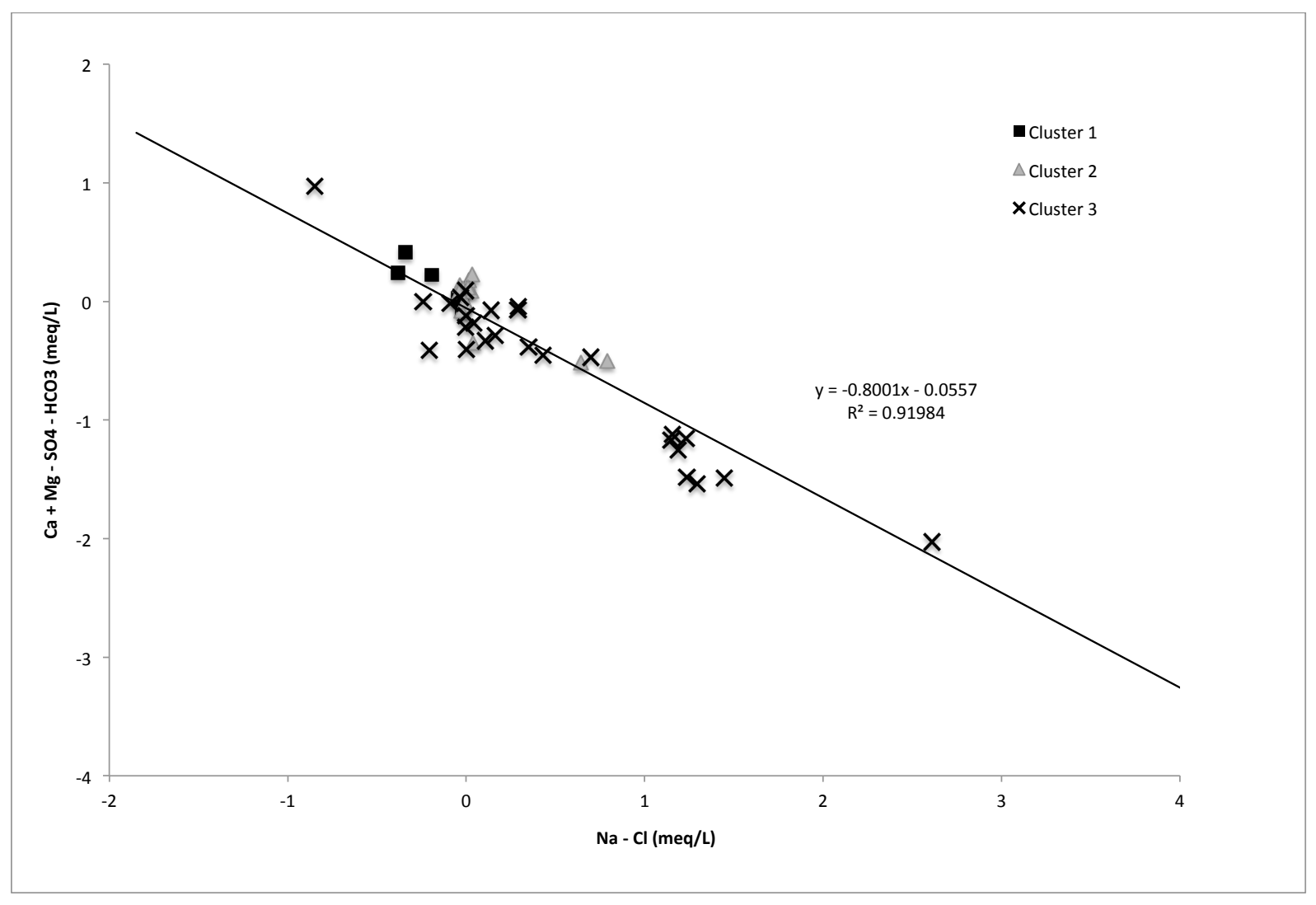


Figure 20: Relation between $\mathrm{Ca}+\mathrm{Mg}$ and $\mathrm{HCO}_{3}{ }^{-}+\mathrm{SO}_{4}$, with groundwater samples labeled according to HCA cluster. Used to differentiate carbonate dissolution and silicate weathering processes

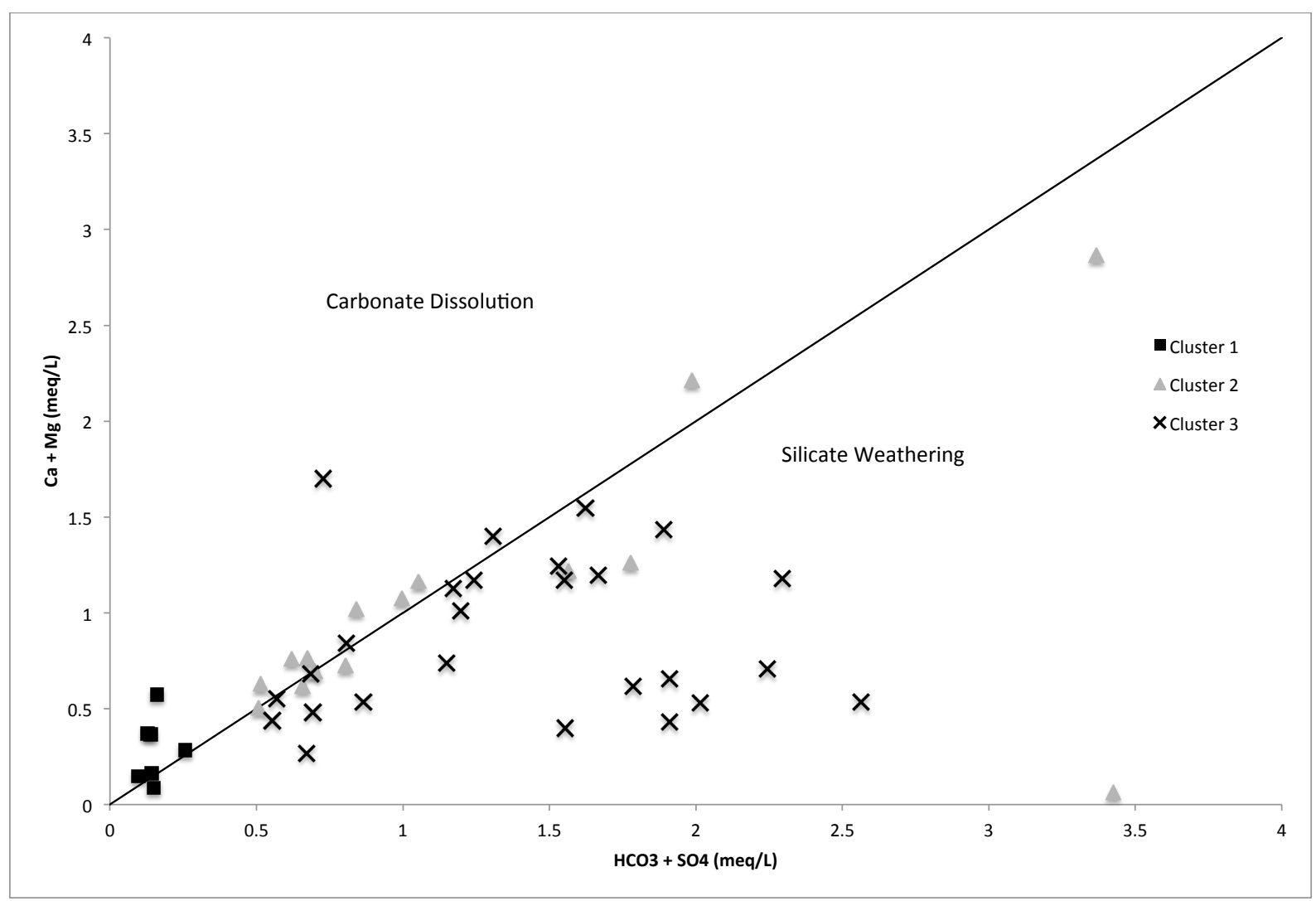




\section{References}

Abate, C. (1993). A numerical modeling approach to estimation of parameters describing groundwater flow in coal-bearing rocks of the Allegheny Plateau. Thesis.

Adams, M. B. (2011). Land application of hydrofracturing fluids damages a deciduous forest stand in west virginia. Journal of Environmental Quality, 40(4):1340-1344.

Alberto, W. D., Maria del Pilar, D., Maria Valeria, A., Fabiana, P. S., Cecilia, H. A., and Maria de los Angeles, B. (2001). Pattern recognition techniques for the evaluation of spatial and temporal variations in water quality. a case study:: Suquia river basin (cordobaâĂŞargentina). Water Research, 35(12):2881-2894.

Appelo, C. A. J. and Postma, D. (2004). Geochemistry, groundwater and pollution. CRC press.

Ashley, R. and Lloyd, J. (1978). An example of the use of factor analysis and cluster analysis in groundwater chemistry interpretation. Journal of Hydrology, 39(3-4):355-364.

Bethke, C. (2016). The Geochemist's Workbench: A users guide to Rxn, Act2, Tact, React, and Gtplot. C. Bethke.

Brantley, S. L., Yoxtheimer, D., Arjmand, S., Grieve, P., Vidic, R., Pollak, J., Llewellyn, G. T., Abad, J., and Simon, C. (2014). Water resource impacts during unconventional shale gas development: The pennsylvania experience. International Journal of Coal Geology, 126:140-156.

Carroll, D. (1959). Ion exchange in clays and other minerals. Geological Society of America Bulletin, 70(6):749-779.

Carroll, D. (2012). Rock weathering. Springer Science and Business Media. 
Cerling, T. E., Pederson, B., and Von Damm, K. (1989). Sodium-calcium ion exchange in the weathering of shales: Implications for global weathering budgets. Geology, 17(6):552554.

Chambers, D. B., Kozar, M. D., White, J. S., and Paybins, K. S. (2012). Groundwater quality in west virginia, 1993-2008. Report, United States Geological Survey.

Cloutier, V., Lefebvre, R., Therrien, R., and Savard, M. M. (2008). Multivariate statistical analysis of geochemical data as indicative of the hydrogeochemical evolution of groundwater in a sedimentary rock aquifer system. Journal of Hydrology, 353(3):294-313.

Davis, J. C. and Sampson, R. J. (1986a). Statistics and data analysis in geology, volume 646. Wiley New York et al.

Davis, J. C. and Sampson, R. J. (1986b). Statistics and data analysis in geology, volume 646. Wiley New York et al.

DiGiulio, D. C., Wilkin, R. T., Miller, C., and Oberley, G. (2011). Investigation of ground water contamination near Pavillion, Wyoming. Office of Research and Development, National Risk Management Research Laboratory.

Eltschlager, K. K., Hawkins, J. W., Ehler, W. C., Baldassare, F., and Dep, P. (2001). Technical measures for the investigation and mitigation of fugitive methane hazards in areas of coal mining.

EQT (2015). Mountain valley pipeline.

Farnham, I. M., Singh, A. K., Stetzenbach, K. J., and Johannesson, K. H. (2002). Treatment of nondetects in multivariate analysis of groundwater geochemistry data. Chemometrics and Intelligent Laboratory Systems, 60(1):265-281. 
Fisher, R. S. and Mullican III, W. F. (1997). Hydrochemical evolution of sodium-sulfate and sodium-chloride groundwater beneath the northern chihuahuan desert, trans-pecos, texas, usa. Hydrogeology journal, 5(2):4-16.

Freeze, R. A., Cherry, J. A., and JA, C. (1979). Groundwater.

Ghesquiere, O., Walter, J., Chesnaux, R., and Rouleau, A. (2015). Scenarios of groundwater chemical evolution in a region of the canadian shield based on multivariate statistical analysis. Journal of Hydrology: Regional Studies, 4:246-266.

Gibbs, R. J. (1970). Mechanisms controlling world water chemistry. Science, 170(3962):1088-1090.

Gross, S. A., Avens, H. J., Banducci, A. M., Sahmel, J., Panko, J. M., and Tvermoes, B. E. (2013). Analysis of btex groundwater concentrations from surface spills associated with hydraulic fracturing operations. Journal of the Air and Waste Management Association, 63(4):424-432.

Gupta, S., Mahato, A., Roy, P., Datta, J., and Saha, R. (2008). Geochemistry of groundwater, burdwan district, west bengal, india. Environmental Geology, 53(6):1271-1282.

Harrison, S. S. (1983). Evaluating system for groundwater contamination hazards due to gas well drilling on the glaciated appalachian plateau. Groundwater, 21(6):689-700.

Helsel, D. R. (1990). Less than obvious-statistical treatment of data below the detection limit. Environmental Science and Technology, 24(12):1766-1774.

Helsel, D. R. (2006). Fabricating data: how substituting values for nondetects can ruin results, and what can be done about it. Chemosphere, 65(11):2434-2439.

Helsel, D. R. and Hirsch, R. M. (1992). Statistical methods in water resources, volume 49. Elsevier. 
Hem, J. D. (1960). Chemical equilibrium diagrams for ground-water systems. Int. Assoc. Sci. Hydrology, Bull, 19:45-53.

Hem, J. D. (1985). Study and interpretation of the chemical characteristics of natural water, volume 2254. Department of the Interior, US Geological Survey.

Hounslow, A. (1995). Water quality data: analysis and interpretation. CRC press.

Ingraffea, A. R., Wells, M. T., Santoro, R. L., and Shonkoff, S. B. (2014). Assessment and risk analysis of casing and cement impairment in oil and gas wells in pennsylvania, 2000-2012. Proceedings of the National Academy of Sciences, 111(30):10955-10960.

Jackson, R. B., Vengosh, A., Darrah, T. H., Warner, N. R., Down, A., Poreda, R. J., Osborn, S. G., Zhao, K., and Karr, J. D. (2013a). Increased stray gas abundance in a subset of drinking water wells near marcellus shale gas extraction. Proceedings of the National Academy of Sciences, 110(28):11250-11255.

Jackson, R. E., Gorody, A. W., Mayer, B., Roy, J. W., Ryan, M. C., and Van Stempvoort, D. R. (2013b). Groundwater protection and unconventional gas extraction: the critical need for field-based hydrogeological research. Ground Water, 51(4):488-510.

Johnson, N., Gagnolet, T., Ralls, R., Zimmerman, E., and Eichelberger, B. (2010). Pennsylvania energy impacts assessment. report 1: Marcellus shale natural gas and wind. the nature conservancy, western pennsylvania conservancy and audubon pennsylvania. the nature conservancy website.

Kappel, W. M., Williams, J. H., and Szabo, Z. (2013). Water resources and shale gas/oil production in the appalachian basin: critical issues and evolving developments. Report 2331-1258, US Geological Survey.

Kozar, M. D. and Brown, D. P. (1995). Location and site characteristics of the ambient 
ground-water-quality-monitoring network in west virginia. U. S. Geol. Survey, Earth Science Information Center, Open File Reports Section.

Kozar, M. D. and Mathes, M. V. (2001). Aquifer-characteristics data for West Virginia. US Department of the Interior, US Geological Survey.

Kumar, M., Ramanathan, A., Rao, M., and Kumar, B. (2006). Identification and evaluation of hydrogeochemical processes in the groundwater environment of delhi, india. Environmental Geology, 50(7):1025-1039.

Kumar, V. S., Amarender, B., Dhakate, R., Sankaran, S., and Kumar, K. R. (2014). Assessment of groundwater quality for drinking and irrigation use in shallow hard rock aquifer of pudunagaram, palakkad district kerala. Applied Water Science, pages 1-19.

Lakshmanan, E., Kannan, R., and Kumar, M. S. (2003). Major ion chemistry and identification of hydrogeochemical processes of ground water in a part of kancheepuram district, tamil nadu, india. Environmental geosciences, 10(4):157-166.

Liu, F., Song, X., Yang, L., Zhang, Y., Han, D., Ma, Y., and Bu, H. (2015). Identifying the origin and geochemical evolution of groundwater using hydrochemistry and stable isotopes in the subei lake basin, ordos energy base, northwestern china. Hydrology and Earth System Sciences, 19(1):551-565.

Loughnan, F. C. (1969). Chemical weathering of the silicate minerals. Report.

Lutz, B. D., Lewis, A. N., and Doyle, M. W. (2013). Generation, transport, and disposal of wastewater associated with marcellus shale gas development. Water Resources Research, 49(2):647-656.

Mathes, M., White, J. S., and Virginia, W. (2006). Methane in West Virginia ground water. US Department of the Interior, US Geological Survey. 
McAuley, S. (1985). Ground-water hydrology of the gauley river basin, west virginia.

McAuley, S. D. and Kozar, M. D. (2006). Ground-water quality in unmined areas and near reclaimed surface coal mines in the northern and central appalachian coal regions, pennsylvania and west virginia. Report, U. S. Geological Survey.

McPhillips, L. E., Creamer, A. E., Rahm, B. G., and Walter, M. T. (2014). Assessing dissolved methane patterns in central new york groundwater. Journal of Hydrology: Regional Studies, 1:57-73.

Meng, S. X. and Maynard, J. B. (2001). Use of statistical analysis to formulate conceptual models of geochemical behavior: water chemical data from the botucatu aquifer in sao paulo state, brazil. Journal of hydrology, 250(1):78-97.

Messinger, T. (1997). Water-quality assessment of the kanawha-new river basin, west virginia, virginia, and north carolina: review of water-quality literature through 1996. Report, U.S. Geological Survey, National Water-Quality Assessment Program.

Messinger, T. and Hughes, C. (2000). Environmental setting and its relations to water quality in the kanawha river basin. national water-quality assessment program. Water Resources Investigations Report. United States Geological Survey, (4020):69.

Molofsky, L. J., Connor, J. A., Wylie, A. S., Wagner, T., and Farhat, S. K. (2013). Evaluation of methane sources in groundwater in northeastern pennsylvania. Groundwater, 51(3):333-349.

Moody, D. W., Carr, J., Chase, E. B., and Paulson, R. W. (1988). National water summary 1986; hydrologic events and ground-water quality. Report 2325. (compiler).

Murtagh, F. and Legendre, P. (2014). Wards hierarchical agglomerative clustering method: Which algorithms implement wards criterion? Journal of Classification, 31(3):274-295. 
Myers, T. (2012). Potential contaminant pathways from hydraulically fractured shale to aquifers. Groundwater, 50(6):872-882.

Nahon, D. B. (1991). Introduction to the petrology of soils and chemical weathering. John Wiley and Sons, Inc.

NYS DEC (2011). Revised draft supplemental generic environmental impact statement on the oil, gas and solution mining regulatory program, well permit issuance for horizontal drilling and high-volume hydraulic fracturing to develop the marcellus and other lowpermeability gas reservoirs.

NYS WRI (2011). Private water well testing in areas impacted by marcellus shale gas drilling.

OH EPA (2014). Recommendations for drinking water well sampling before oil and gas drilling.

Ollier, C. (1984). Weathering. Longman Group.

Osborn, S. G., Vengosh, A., Warner, N. R., and Jackson, R. B. (2011). Methane contamination of drinking water accompanying gas-well drilling and hydraulic fracturing. Proc Natl Acad Sci U S A, 108(20):8172-6.

PA DEP (2010). Recommended basic oil and gas pre-drill parameters; pa dep fact sheet 5500- fs-dep4300.

Parkhurst, D. L. and Appelo, C. (1999). User's guide to phreeqc (version 2): A computer program for speciation, batch-reaction, one-dimensional transport, and inverse geochemical calculations.

Piper, A. M. (1944). A graphic procedure in the geochemical interpretation of waterâǍ analyses. Eos, Transactions American Geophysical Union, 25(6):914-928. 
Powell, J. D. and Larson, J. D. (1985). Relation between ground-water quality and mineralogy in the coal-producing Norton Formation of Buchanan County, Virginia. Department of the Interior, US Geological Survey.

Puente, C. (1984). West virginia ground water resources. National Water Summary, pages 439-446.

Puls, R. W. and Barcelona, M. J. (1989). Ground water sampling for metals analyses. Report, United States Environmental Protection Agency, Office of Research and Development.

R Core Team (2013). R: A language and environment for statistical computing.

Rahm, B. G., Bates, J. T., Bertoia, L. R., Galford, A. E., Yoxtheimer, D. A., and Riha, S. J. (2013). Wastewater management and marcellus shale gas development: trends, drivers, and planning implications. J Environ Manage, 120:105-13.

Rahm, B. G. and Riha, S. J. (2014). Evolving shale gas management: water resource risks, impacts, and lessons learned. Environmental Science: Processes and Impacts, 16(6):1400-1412.

Rainwater, F. H. and Thatcher, L. L. (1960). Methods for collection and analysis of water samples. US Government Printing Office.

Rajmohan, N. and Elango, L. (2004). Identification and evolution of hydrogeochemical processes in the groundwater environment in an area of the palar and cheyyar river basins, southern india. Environmental Geology, 46(1):47-61.

Repetski, J. E., Ryder, R. T., Avary, K. L., and Trippi, M. H. (2005). Thermal Maturity Patterns (CAl and \% RO) in the Ordovician and Devonian Rocks of the Appalachian Basin in West Virginia. US Geological Survey. 
Rozell, D. J. and Reaven, S. J. (2012). Water pollution risk associated with natural gas extraction from the marcellus shale. Risk Anal, 32(8):1382-93.

Sharma, S., Mulder, M. L., Sack, A., Schroeder, K., and Hammack, R. (2014). Isotope approach to assess hydrologic connections during marcellus shale drilling. Ground Water, $52(3): 424-33$.

Sheets, C. J. and Kozar, M. D. (2000). Ground-water quality in the appalachian plateaus, kanawha river basin, west virginia. Report 99-4269. [distributor].

Soeder, D. (2011). Preliminary analysis of the weathering potential of marcellus shale drill cuttings. In Geological Society of America Northeast Section Annual Meeting, Pittsburgh, $P A$.

Soeder, D. J. and Kappel, W. M. (2009). Water resources and natural gas production from the Marcellus Shale. US Department of the Interior, US Geological Survey Reston, Virginia.

States, S., Cyprych, G., Stoner, M., Wydra, F., Kuchta, J., Monnell, J., and Casson, L. (2013). Brominated thms in drinking water: A possible link to marcellus shale and other wastewaters. Journal - American Water Works Association, 105:E432-E448.

Stiff, H. A. (1951). The interpretation of chemical water analysis by means of patterns. Journal of Petroleum Technology, 3(10):15-3.

Svensson, T., Lovett, G. M., and Likens, G. E. (2012). Is chloride a conservative ion in forest ecosystems? Biogeochemistry, 107(1-3):125-134.

US EPA (2012). Flowback and produced water: 2012 progress report : study of the potential impacts of hydraulic fracturing on drinking water resources. Report, U.S. Environmental Protection Agency, Office of Research and Development. 
US EPA (2015). Environmental protection agency.

U.S. Geological Survey (2001). National water information system.

Vengosh, A., Jackson, R. B., Warner, N., Darrah, T. H., and Kondash, A. (2014). A critical review of the risks to water resources from unconventional shale gas development and hydraulic fracturing in the united states. Environ Sci Technol, 48(15):8334-48.

Vidic, R., Brantley, S., Vandenbossche, J., Yoxtheimer, D., and Abad, J. (2013). Impact of shale gas development on regional water quality. Science, 340(6134).

Warner, N. R., Jackson, R. B., Darrah, T. H., Osborn, S. G., Down, A., Zhao, K., White, A., and Vengosh, A. (2012). Geochemical evidence for possible natural migration of marcellus formation brine to shallow aquifers in pennsylvania. Proc Natl Acad Sci U S A, 109(30):11961-6.

White, J. and Mathes, M. (2006). Dissolved-gas concentration in ground water in west virginia. Data Series, 156.

Whiticar, M. J. (1999). Carbon and hydrogen isotope systematics of bacterial formation and oxidation of methane. Chemical Geology, 161(1):291-314.

Wilde, F., Radtke, D., Gibs, J., and Iwatsubo, R. (1998). National field manual for the collection of water-quality data. US Geological Survey Techniques of Water-Resources Investigations, Book, 9.

Wilde, F. D. (1999). Chapter a4. collection of water samples. Report, Geological Survey (US).

Wu, J., Li, P., Qian, H., Duan, Z., and Zhang, X. (2014). Using correlation and multivariate statistical analysis to identify hydrogeochemical processes affecting the major ion chemistry of waters: a case study in laoheba phosphorite mine in sichuan, china. Arabian Journal of Geosciences, 7(10):3973-3982. 
WV GES (2015). West virginia geologic and economic survey.

Wyrick, G. G. and Borchers, J. W. (1981). Hydrologic effects of stress-relief fracturing in an appalachian valley. Report, GPO.

Xing, L., Guo, H., and Zhan, Y. (2013). Groundwater hydrochemical characteristics and processes along flow paths in the north china plain. Journal of Asian Earth Sciences, 70:250-264. 